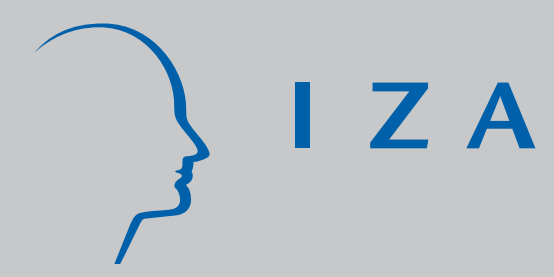

IZADP No. 3761

The Role of Information and Institutions in Understanding the Black-White Gap in Self-Employment

Ruth Uwaifo Oyelere

Willie Belton

October 2008 


\title{
The Role of Information and Institutions in Understanding the Black-White Gap in Self-Employment
}

\author{
Ruth Uwaifo Oyelere \\ Georgia Institute of Technology \\ and IZA \\ Willie Belton \\ Georgia Institute of Technology
}

Discussion Paper No. 3761

October 2008

\author{
IZA \\ P.O. Box 7240 \\ 53072 Bonn \\ Germany \\ Phone: +49-228-3894-0 \\ Fax: +49-228-3894-180 \\ E-mail: iza@iza.org
}

\begin{abstract}
Any opinions expressed here are those of the author(s) and not those of IZA. Research published in this series may include views on policy, but the institute itself takes no institutional policy positions.

The Institute for the Study of Labor (IZA) in Bonn is a local and virtual international research center and a place of communication between science, politics and business. IZA is an independent nonprofit organization supported by Deutsche Post World Net. The center is associated with the University of Bonn and offers a stimulating research environment through its international network, workshops and conferences, data service, project support, research visits and doctoral program. IZA engages in (i) original and internationally competitive research in all fields of labor economics, (ii) development of policy concepts, and (iii) dissemination of research results and concepts to the interested public.
\end{abstract}

IZA Discussion Papers often represent preliminary work and are circulated to encourage discussion. Citation of such a paper should account for its provisional character. A revised version may be available directly from the author. 


\section{ABSTRACT \\ The Role of Information and Institutions in Understanding the Black-White Gap in Self-Employment}

It has been well documented in the literature that ethnicity matters significantly in the determination of self-employment rates. In particular, African-American self-employment rates lag far behind rates for other racial groups. Similarly, the literature also provides evidence of the long lived nature of institutions and the link between institutions and decision making. After controlling for the appropriate factors that can lead to self-employment differentials, we provide an explanation for the self-employment gap that still exists between African-Americans and White Americans. We focus on the important role of repeated negative institutional shocks and how such shocks influence the development of an information matrix as well as the transmission of information across time and generations. We show that African-Americans who were less likely to be influenced by negative institutional shocks and the information stock created from these experiences, have similar self-employment rates to comparably situated White Americans.

JEL Classification: J15, J01, J24, D80

Keywords: self-employment, information, institutions, African-American

Corresponding author:

Ruth Uwaifo Oyelere

School of Economics

Georgia Institute of Technology

781 Marietta Street

Atlanta, GA 30318

USA

E-mail: ruth.uwaifo@econ.gatech.edu 


\section{Introduction}

It has been well documented in the literature that ethnicity matters in the determination of selfemployment rates. ${ }^{1}$ In particular, African-American self-employment rates lag far behind those of other ethnic groups as White-Americans are three times more likely to be self-employed. The causes of low African-American self-employment includes significant differences in demographic factors such as education, the Great Black Migration of the 1950s, the convergence in education, discrimination in lending, differences in financial capital, and disparities in generational transfers of human capital i.e., having parents who were self-employed.

Though the literature has attempted to address the issue of family background and it's role in the success or lack there of Black-owned businesses, there has been little attention given to the role of institutions and their subsequent long-lived impact on expectations of self-employment success across ethnic groups. In addition, to the best of our knowledge there has been no research on the impact of institutional shocks on information stocks and the self-employment entry decision.

In this paper we attempt to explain low self-employment patterns among African-Americans using a novel racial decomposition that allows identification of the role of past institutions in the self-employment decision. We compare the self-employment probabilities for racial subgroups to that of White Americans with U.S. born parents,(WAUBP), in an attempt to examine the impact of political and social institutions, as well as information/learning processes on the incidence of self-employment for Blacks in general and African-Americans in particular.

Understanding the cause and consequences of the Black-White self-employment gap is important for a number of reasons. First, policy-makers care about the gap because historically, patterns of business ownership seem to exacerbate racial tensions. For example, racial tension between Asians and African-Americans in many American cities is due, in part, to the presence of Asian-owned businesses located in the heart of the African-American community. Second, selfemployment/entrepreneurship has been suggested to pose the best opportunity for under-represented groups to raise themselves out of poverty and realize the American dream. Finally, the growth of the U.S. economy during the late 1990s, the impact of government instituted affirmative actions programs, and the scope of "emerging" lines of Black-owned business has led many to argue that there has been a significant increase in business opportunities for African-Americans. ${ }^{2}$ Hence, some

\footnotetext{
${ }^{1}$ Bates (1987); Borjas and Bronars (1989); Meyer (1990); Fairlie (1999); Fairlie and Meyer (1996)

${ }^{2}$ Bates(1997 and 2006), Boston and Ross (1997)
} 
have questioned the continued need for government sponsored affirmative action programs which have been responsible for significantly increasing African-American self-employment rates.

Using data from the 1994-2002 Consumer Population survey (CPS) from IPUMS (see King et al 2004), we estimate the probability of self-employment for various ethnic groups relative to that of White Americans with U.S. born parents (WAUBP). Controlling for demographic factors and other explanatory variables suggested in the literature, we first provide evidence of the well documented Black-White self-employment gap. We then attempt to find evidence, based on recent literature, of the hypothesized higher self-employment rates among recent immigrants. We subsequently explore the potential impact of the relative economic standing of the immigrant's home country i.e., we examine the impact of developed verses developing nations status of the immigrant's country of origin, on the likelihood of self-employment. Social and economic barriers as well as other obstacles faced by immigrants in the formal labor market could suggest a predisposition to seek self-employment. Given this fact, we examine the impact of citizenship through naturalization on the likelihood of self-employment. Finally, we provide evidence of the importance of social and political institutional shocks as well as the impact of generational information sets derived from institutional experiences on the African-American self-employment decision. In effect, we examine how and why two groups of U.S born African-Americans could be exposed to different historical information sets creating over time different generational information matrices, leading to different self-employment outcomes. To empirically examine this difference, we decompose the African-American and the White-American sample populations along the lines of parental country of origin, in effect, we compare the likelihood of self-employment for sample members who were born to immigrant parents relative to those with U.S. born parents.

Initially, we find evidence of a self-employment gap between Blacks and Whites in the period considered as Blacks have a 5.5\% less probability of self-employment relative to Whites. In addition, we find that while foreign Whites have a higher or similar probability of self-employment to that of White Americans, foreign Blacks have a higher probability of self-employment than do AfricanAmericans but lower than American born and foreign Whites. Specifically, we find that foreign Whites have a $3.9 \%$ higher probability of self-employment than do White Americans the positive difference is driven by Whites from developed countries (DC). In contrast, foreign Whites from less developed countries (LDC) have a similar self-employment probability to that of White Americans. Higher self-employment probabilities for foreign Whites from developed countries relative to Amer- 
ican Whites, provides evidence in support of the thesis that immigrants tend to gravitate towards self-employment as institutional barriers, foreign status, language..,etc, tend to limit entry into the formal labor market. We find that naturalized Whites, who are impacted by fewer institutional constraints, tend to pursue self-employment at a lower rate than do foreign Whites from developed countries but at a higher rate than do American Whites. This result provides more evidence in favor of the impact of institutional barriers on self-employment outcomes.

We find that not all African-Americans have low self-employment probabilities i.e., a subgroup of African-Americans have a similar self-employment probability to that of White Americans. After controlling other factors that affect self-employment, including a proxy for wealth, we find that African-Americans who are American born but have foreign born parents have similar selfemployment probabilities to that of American born Whites, whereas African-Americans with U.S. born parents have a significantly lower probability of self-employment relative to White Americans. In effect, African-Americans who were more likely to be directly or indirectly exposed, over time, to the negative information set derived from repeated formal and informal institutional shocks are significantly less likely to seek self-employment. To provide evidence of the robustness of our results, we examine whether higher self-employment probabilities are unique to all Americans with foreign born parents relative to those with U.S. born parents. We decompose our sample of White Americans as we did African-Americans and find no difference in self-employment outcomes for White Americans with foreign born parents relative to White Americans with U.S. born parents. The question then becomes why do White Americans with U.S. born parents,WAUBP, White Americans with foreign born parents, WAFBP, and African-Americans with foreign born parents, AAFBP, all share similar self-employment-probabilities in our 1994 to 2002 data set, but African-Americans with U.S. born parents, AAUBP, do not. ${ }^{3}$ Our explanation is that available current and historical information sets impacts individual decisions to pursue self-employment. We argue that though the three groups with similar probabilities may have only slightly different historical information matrices, they all lack exposure to the negative institutional shocks that impacted the historical information matrix of AAUBP, leading to their higher self-employment probabilities.

This paper contributes to the literature in three ways: First, we highlight the importance of decomposing the population into more unique categories when trying to understand and make statements regarding the probability of self-employment. Our paper is the first to highlight the

\footnotetext{
${ }^{3}$ Henceforth in this paper, we will refer to this different subgroups by the acronyms highlighted.
} 
fact that not all Black subgroups have lower self-employment probabilities relative to WAUBP. Second, we highlight the importance of examining historical institutional changes and their impacts on ethnic self-employment probabilities. Third, we highlight an additional reason for the hypothesized Black/White self-employment gap, by providing an argument as to why repeated institutional

shocks and business failures may have created an information matrix which engenders the perception in the African-American community that self-employment is significantly more risky than actual current conditions dictate. This perception leads to lower self-employment probabilities for African-Americans relative to other ethnic/racial groupings across generations.

The rest of the paper is organized as follow. The second section of this paper provides a detailed review of the literature related to self-employment and race. In section 3 we develop our own explanation for the persistent gap in Black/White self-employment. Sections 4 and 5 highlights data used, describes the econometric approach in detail, and analyzes what we learn through unique population data decompositions. Section 6 outlines the identification strategy, provide econometric results, and also offer robustness checks of key results. The final section contains a discussion of inferences, provides conclusions, and offers recommendations.

\section{Literature Review}

Past research on the causes of low African-American self-employment rates have fallen into five areas; demographic disparities, liquidity disparities, entry into and exit out of high verses low entry barrier industries, generational transfer of human and financial capital disparities, and cultural disparities. Fairlie (1999) examining self-employment entry decision finds that graduation from college relative to dropping out of high school does increase the probability of self-employment more for Whites than for Blacks. However, the small size of the education coefficient in the logit regression indicates that education has a weak relationship with the self-employment entry decision. Looking across time, Fairlie and Meyer (2000) using the Smith and Welch (1989) decomposition method examines the influence of demographic factors on racial trends in self-employment. They calculate the separate contribution of age, family, education, and region. They find that the Great Black migration, racial convergence in education levels, family background, and regional locations did not explain the constancy of the racial gap in self-employment during the 1960 to 1990 time frame.

Bates (1987) shows that racial difference in financial capital has a significant impact on the racial patterns of business failure. In complementary research examining self-employment entry rates, 
Blau and Graham (1990) and Fairlie (1999) demonstrate that racial differences in financial asset levels provide an important contribution to the Black/White gap in entry rates to self-employment. More recently, Blanchflower, Levine and Zimmerman (2003) show that lending practices by financial institutions appear to exacerbate Black/White differences in access to financial capital. They argue that in the case of start-ups as well as existing small businesses, banks are the primary source of debt capital and this capital is more readily available to White entrepreneurs than to similarly situated Blacks. Evans and Leighton (1989) show that all else remain equal, people with greater family assets are more likely to switch to self-employment. Though Evans and his collaborators conclude that capital and liquidity constraints bind, there are other alternative explanations that could produce the same results. For example, individuals could forgo leisure and start their own business to build up family assets producing a correlation between family assets and movements in self-employment even if capital constraints do not exist. Blanchflower and Oswald (1998) also provide evidence of the role of wealth-transfers on self-employment. Using British data, they find that the probability of self-employment depends positively upon whether the individual ever receives an inheritance or gift.

Lofstrom and Bates (2007) criticize the self-employment literature in its use of a one size fit all econometric approach to modeling the self-employment decision. They argue that industry context heavily shapes the impact of owner resource endowments on small firm entry and exit i.e., differences in entry barriers typify different industry subgroups. They find that Blacks are more likely to exit low-barrier lines of business than similarly situated Whites. However, among highly educated Blacks the link between exit rates and race is weak for high barrier lines of small business. Fairlie and Myer (2007) find that Black firms and White firms concentrate in different industries. Black firms tend to be under represented in construction, manufacturing, whole sale trade, agricultural services, finance, insurance, and real estate but are more concentrated in transportation, communications, public utilities, and personal services. These industry differences are associated with worse outcomes among Black-owned firms.

Generational transfer of human capital is another factor highlighted in the literature. Theoretically, one would expect a strong intergenerational link in self-employment given the transmission of informal business and/or managerial knowledge as well as the transfer of financial and real capital assets from one generation to the next. Lentz and Laband (1990) find that $53 \%$ of a sample of selfemployed proprietors from the National Federation of Independent Business had a self-employed 
parent. Fairlie and Robb (2007) find that Black business owners are much less likely to have a selfemployed family member than are White business owner. This difference however, is important in explaining disparities in Black/White self-employment rates but is unimportant in explaining racial disparities in profits, sales, and employment between Black- and White-owned businesses.

Frazier $(1957,1965)$ was one of the first to hypothesize that the lack of business tradition, as a result of slavery, was partially responsible for the failure of African-Americans to achieve entrepreneurial success. Sowell $(1991,1994)$, Light (1980), Light and Gold (2000), and others have focused on the African-American culture as one of the important factors in limiting entrepreneurial success. Light (1980) asserted that Black cultural values do not foster entrepreneurial activity. Light and Gold (2000) soften their original claim by acknowledging that Blacks have indeed experienced severe discrimination. Feagan and Imani (1994) argue that most immigrant groups endured formidable obstacles with respect to entrepreneurship, however, these challenges do not compare in kind or degree to the sweeping exclusionary practices that historically kept African-Americans out of many business areas. Butler (2005) argues that when examining historical practices of AfricanAmericans in the context of the sociology of entrepreneurship, African-American traditions suggest a strong entrepreneurial culture. Rather than accepting anecdotal evidence as fact, Darity (2005) proposes the emergence of "stratification economics" which constitutes a systematic and empirically grounded approach rather than the conventional antidotally grounded approach to disparity. Stratification economics suggest that we decompose the data based on the impact of structural and intentional processes that generate hierarchy and corresponding income and wealth inequalities between ascriptively distinguishable groups.

\section{The Role of Information and Institutions in Black Reluctance in self-employment}

The self-employment literature, save Fairlie and Meyer (1996) and Darity (2005), has generally examined Blacks as one homogenous group and concluded, in most cases, that there is a significant gap between Black and White self-employment rates. Bogan and Darity (2008) argue that any examination of the evolution of African-American entrepreneurship must include consideration of the long, arduous, and diverse road of the African-American entrepreneur which includes exposure to slavery, "Jim Crow" laws, and institutional racism. Early Black entrepreneurs were freed slaves functioning in personal services and trades that Whites perceived to be too menial. By 1890 an 
estimated 5000 Blacks operated businesses (Higgs 1977). Bogan and Darity (2008) argue that the Great Migration in the early 1900s fundamentally changed the landscape for Black enterprise. African-American entrepreneurs faced increased racial hostility and increased competition from other immigrant groups as Black populations increased in Northern cities. Racial tension severely damaged the relationship between Black service providers and affluent Whites (Boyd 1990b). In the South between 1880 and 1930 there was a substantial decumulation of property ownership by Blacks as Jim Crow laws supported White terrorism and ultimate land seizure (Darity and Frank 2003). The Southern Homestead Act which was intended to provide freedmen the first opportunity to acquire public lands in Alabama, Arkansas, Florida, Louisiana, and Mississippi was hugely unsuccessful and de facto transferred land to Whites (McPherson, 1964). Conversely, the Homestead Act of 1862 parceled out farmland to German and Scandinavian immigrants facilitating entrepreneurial activity and social mobility of many European groups. Further, the National Labor Relations act of 1937 institutionalized collective bargaining which provided Italian, Polish, and Jewish immigrants with both job and income security (Boyd, 1990b).

Black entrepreneurs found that legal and social barriers made it impossible to compete in the general market place and sought to focus their efforts on servicing their own community within the walls created by discrimination and segregation. Brimmer (1966) argues that segregation did have positive effects on the earnings of self-employed Blacks as social and demographic changes led to the collapse of Black businesses serving affluent Whites but created a protected market for Black entrepreneurs providing services to Blacks. The 1960s brought increased social awareness, civil rights legislation, and profit seeking large corporations made White-owned businesses increasingly available to Black consumers. Because Black businesses were generally smaller and under capitalized, Black entrepreneurs found themselves unable to compete in terms of price and quality with more well established White-owned firms. In effect, the desegregation of the 1960s, despite its numerous benefits, implicitly provided a significant negative shock to the Black entrepreneur.

Shifts in the formal and informal institutional landscape have, over time, adversely impacted African-American entrepreneurial development. Douglas North (1973) and (2005) defines institutions as the formal and informal rules which govern societal interactions. These rules represent the institutional scaffolding on which communities move through time and provide context for understanding the basic legal, political, economic and social paths of societal outcomes. When formal rules and processes are reinforced over time through the realization of predicted outcomes, they 


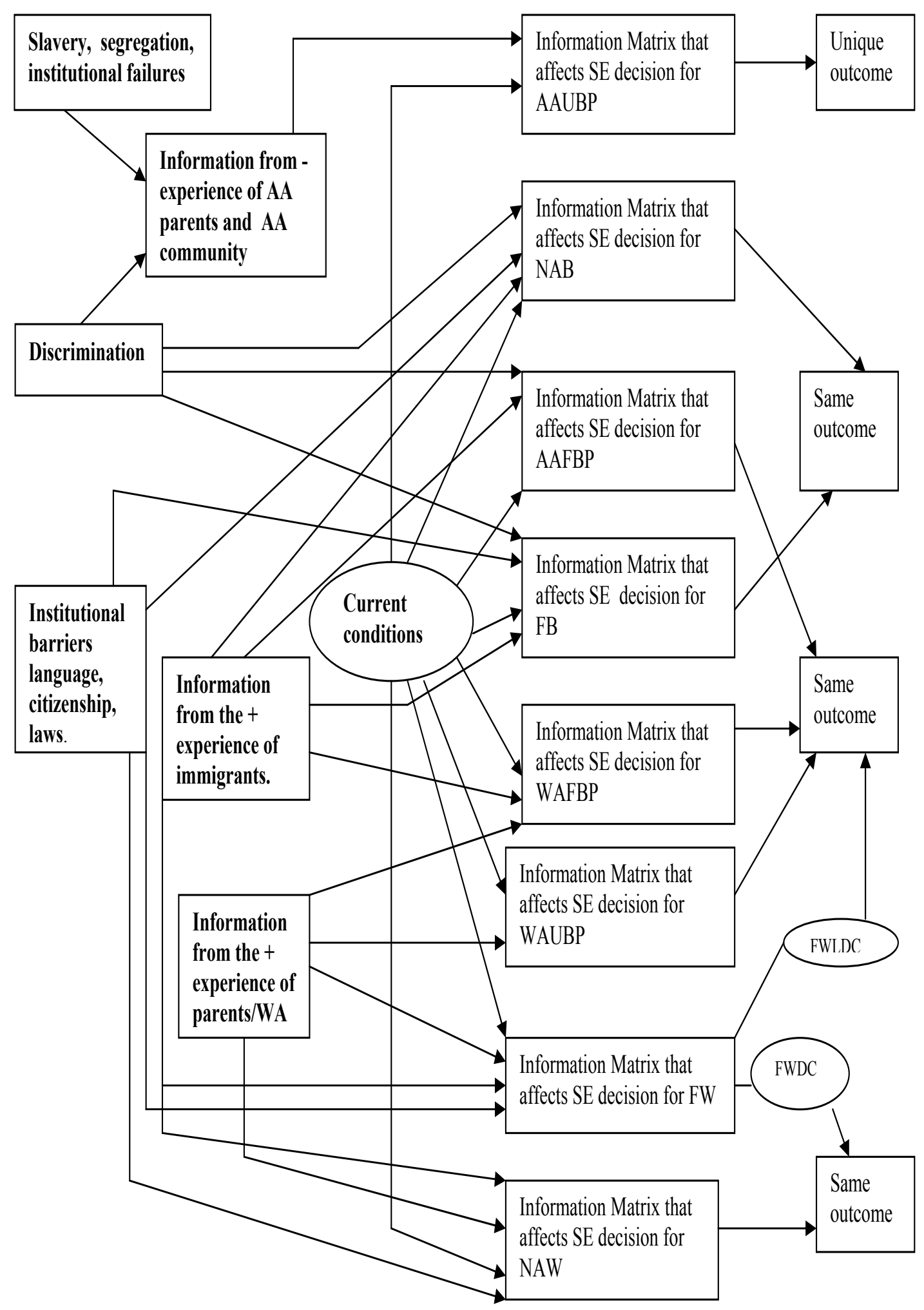

Figure 1: Determination of the Information Magtrix for Self Employment decision across groups 
tend to become a part of the societal fiber leading to more entrenched informal methodologies that impact future outcomes in the community. These entrenched methodologies tend to be long-lived as perspectives and perceptions of established outcomes become self-reinforcing and are passed from one generation to the next through word of mouth and/or perceived fundamental truism. Acemoglu, Johnson, and Robinson (2001a) and (2002) using North's definition of institutions have examined empirically the impact of institutions on downstream outcomes in terms of economic growth across nation states. They show that the established colonial institutions of the 14 th century helps to explain divergent growth paths of former European colonies during the 1980s and 1990s. This research shows that not only do institutions matter but their impacts are long-lived. If colonial institutions implanted during the 14th century have been shown to impact the growth of former colonies some 300 to 400 years later then examining African-American entrepreneurship in the context of the many formal and informal institutional changes discussed above may provide insight as to why Black entrepreneurship lags significantly behind that of Whites and other immigrant groups.

Even if one is skeptical about the long-term influence of institutional change on African-American entrepreneurial activity, it is clear that the Black entrepreneur has experienced a number of significant set backs in terms formal and informal, legal and illegal activities that has negatively impacted the actual and perceived probability of entrepreneurial success. Figure 1 show the different information channels faced by ethnic/racial groups. This figure highlights the unique outcome for African-Americans brought on by exposure to slavery, segregation, and other institutional barriers as well as the impact of information derived from experiences of African-Americans business failure across time. These failures can be traced, over time, to legal barriers, discrimination, undercapitalization, changes in the legal and social climate, and many other shifts in the economic, social and political landscape. Figure 2 is a simple depiction of some of the historical shocks and events that African-Americans have experienced over time that helps define the information matrix of this group, creating the unique outcome highlighted in Figure 1. Whatever the reason for business failures across time, there has been spells of significant African-American business failure that has become embedded in the social fabric of the community. In effect, the reality of self-employment outcomes in the African-American community has created a disincentive for African-American selfemployment as well as provided a deeply rooted perception, transferred across generations, that the probability of business failure for the African-American is significantly higher than that of White Americans, and higher than current conditions dictate. The disincentive for self-employment and 
the learning process which provides a unique information set regarding the real and/or perceived high probability of African-American business failure could account for the significant gap between African-American and Caucasian-American self-employment.

\section{Description of Datasets}

To provide evidence of the indirect impact of institutions on African-American probability of selfemployment, we make use of the March Current Population Survey (CPS). The CPS is a monthly U.S. household survey conducted jointly by the U.S. Census Bureau and the Bureau of Labor Statistics. The CPS samples are multi-stage stratified samples. We extract these data from IPUMSCPS which is microdata that provides information about individual persons and households (see King et al 2004 for details on this data). The IPUMS-CPS data is available for 46 years (19622007). However, we make use of data from 1994-2002 for two reasons: First, the nature of our identification strategy requires the existence of particular variables in the data set which were, in many cases, not surveyed until 1992. For example, parents birth place is used as a control variable in our analysis but was not available in the CPS before 1992. Second, post 2002 the coding for race changed significantly as the variable that captures race was broken down into several subcategories making it more difficult to easily identify the groups of interest. Specifically prior to 2003, the number of race categories ranged from 3 (White, Negro, and other) to 5 (white, black, American Indian/Eskimo/Aleut, Asian or Pacific Islander, and other). The three category breakdown of race was thought to be too simplistic and was abandoned in 1988 for the more empirically useful five category breakdown. Beginning in 2003, respondents could report more than one race, and the number of codes rose to 21 making it more difficult to compare data prior to 2003 with data post 2003 with respect to race. Individuals who classed themselves as black previously could now identify themselves as biracial and similarly others who identified themselves as white prior to this change could also claim multiracial. One of the advantages of using the CPS via IPUMS is that it makes

cross-time comparisons using the March CPS data more feasible as variables in IPUMS-CPS are coded identically or "harmonized" for 1962 to 2007. Table 1 is a summary of the data used by race and citizenship. 


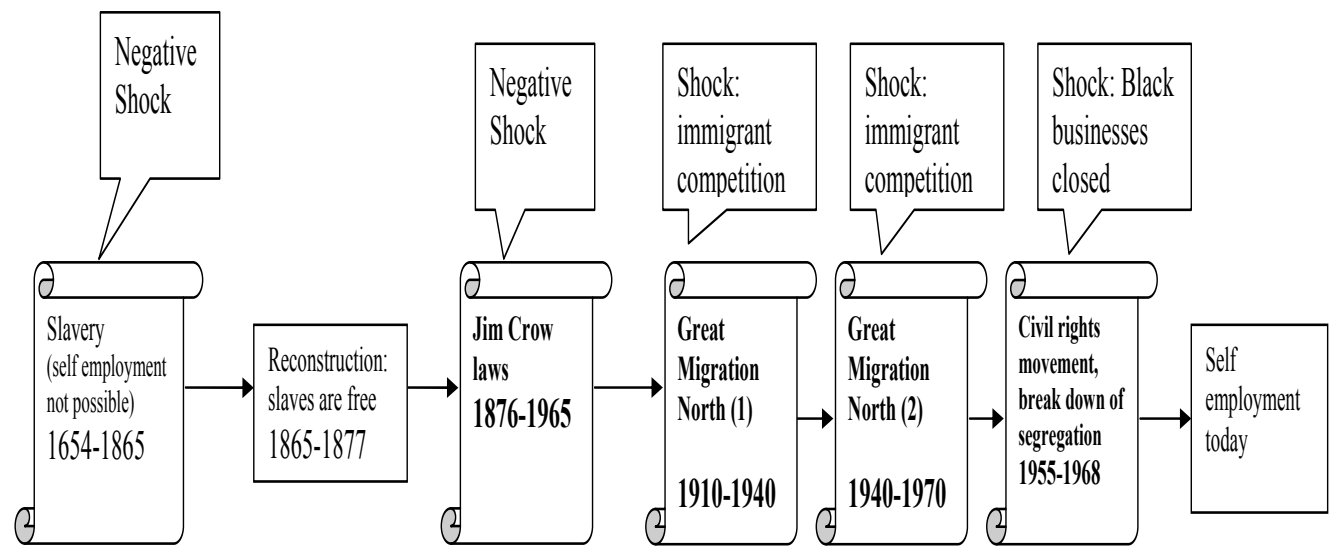

Figure 2: Institutional Shocks Impacting the African-American Community 
Table 1: Breakdown of Data by Race/Native subgroups

\begin{tabular}{ccc}
\hline \hline & & \\
Variable & Observations & $\%$ \\
\hline Black US born & 127,617 & 9.77 \\
\hline White US born & 998,205 & 76.40 \\
Black Naturalized & 3,374 & 0.26 \\
White Naturalized & 31,427 & 2.41 \\
Black Foreign & 6,163 & 0.47 \\
White Foreign & 68,386 & 5.23 \\
American Indian/Aleut/Eskimo & 18,368 & 1.41 \\
Asian or Pacific Islander & 47,487 & 3.63 \\
Other (single) race & 5,579 & 0.43 \\
\hline \hline
\end{tabular}

\section{$5 \quad$ Empirical Strategy and Results}

\subsection{General econometric model}

To provides evidence of the impacted of negative information, created via repeated institutional shocks and/or realized business failures on the self-employment probabilities of African-Americans relative to White-Americans, we estimate a variants of equation 1 making use of three different empirical strategies. Equation 1 is a simple self-employment probability model:

$$
\operatorname{Pr}(Y=1)=\alpha+\phi X+\kappa Z+\theta W+\psi R+\epsilon
$$

where $Y$ is self-employed, $X$ is a matrix of demographic variables that could potentially impact the probability of choosing self-employment. Variables included in this matrix are sex, education, number of children in the family, size of the family, and marital status. $Z$ is a matrix of dummy variables including year dummies, and region and state fixed effects. The vector $W$ captures the proxy for wealth. In this paper, we make use of two proxies for wealth; interest income and dividend income. As defined in the CPS, interest income captures how much pre-tax income (if any) the respondent received from interest on saving accounts, certificates of deposit, money market funds, bonds, treasury notes, IRAs, and/or other investments which paid interest. In contrast, dividend income captures what respondents received from stocks and mutual funds during the previous calendar year. Interest income is clearly a more broad measure and provides a better proxy of wealth, however, the dividend income wealth proxy allows examination of the robustness of our results. We 
estimate models using both wealth proxies and get similar results, however, we focus primarily on results obtained using interest income as the wealth proxy. ${ }^{4}$

In equation 1, the dependent variable is a binary indicator which takes on a value of 1 if an individual is self-employed and a value of 0 if the individual is a wage earner. The $\mathrm{R}$ matrix contains race related variables and our unique race decomposition strategy which allows estimation of a vector of coefficients $\psi$. Unless explicitly stated otherwise, the baseline comparison group for the racial dummy variables is U.S. born Whites. Finally, $\epsilon$ is a vector of error terms.

To estimate equation 1 we make use of logit, linear, and probit models. In addition to presenting the estimated coefficients from the probit models, we also present the marginal effects. These effects represent the marginal impact of an infinitesimal change in each independent continuous variable on the probability of self-employment, providing the most straight forward interpretation of estimated results from probit models. For race dummy variables, the interpretations are slightly different. The estimates capture the marginal effect of a change in the probability of being self-employed for a particular racial group relative to the baseline group. Similarly, for ease of interpretation, we present the odds ratio using the logit model. ${ }^{5}$ We also make use of linear probability specifications of the binary regression model. These models also provides ease of interpretation, however care must be taken because unless restrictions are placed on estimates, coefficients can imply probabilities outside the unit interval.

We initially estimate a parsimonious form of equation 1 with minimal controls. We then extend the model by including increasing numbers of control variables that help in identifying the impact of institutions and information on the relative self-employment probabilities of Blacks and Whites in the U.S. This step by step approach allows examination of the impact of including each additional control variable as well as each additional racial decomposition on self-employment probabilities for different groups within the population. In addition, this approach creates an opportunities to replicate and build on earlier self-employment research results. Finally, the multiple model approach as well as multiple estimation strategies serves as robustness checks of our results. 
Table 2: Evidence of the Racial Self-Employment Gap

\begin{tabular}{|c|c|c|c|c|c|c|c|c|c|c|}
\hline \multirow{2}{*}{ Variable: } & \multicolumn{5}{|c|}{ Saving Indicator 1} & \multicolumn{5}{|c|}{ Savings Indicator 2} \\
\hline & $\begin{array}{l}\operatorname{logit} \\
(1)\end{array}$ & $\begin{array}{c}\text { logistic } \\
(2)\end{array}$ & $\begin{array}{c}\text { Linear } \\
(3)\end{array}$ & $\begin{array}{c}\text { Probit } \\
(4)\end{array}$ & $\begin{array}{c}\text { dprobit } \\
(5)\end{array}$ & $\begin{array}{c}\operatorname{logit} \\
(6)\end{array}$ & $\begin{array}{c}\text { logistic } \\
(7)\end{array}$ & $\begin{array}{c}\text { Linear } \\
(8)\end{array}$ & $\begin{array}{c}\text { Probit } \\
(9)\end{array}$ & $\begin{array}{c}\text { dprobit } \\
(10)\end{array}$ \\
\hline & 1 & 2 & 3 & 4 & 5 & 6 & 7 & 8 & 9 & 10 \\
\hline logincint & $\begin{array}{c}0.095^{*} \\
(0.003)\end{array}$ & $\begin{array}{c}1.1^{*} \\
(0.003)\end{array}$ & $\begin{array}{c}0.01^{*} \\
(0.0003)\end{array}$ & $\begin{array}{c}0.05^{*} \\
(0.002)\end{array}$ & $\begin{array}{c}0.009^{*} \\
(0.0003)\end{array}$ & & & & & \\
\hline & 29.91 & 29.91 & 30.14 & 29.63 & 29.63 & & & & & \\
\hline logdefincdiv & & & & & & $\begin{array}{l}0.054^{*} \\
(0.005)\end{array}$ & $\begin{array}{l}1.055^{*} \\
(0.005)\end{array}$ & $\begin{array}{c}0.007^{*} \\
(0.001)\end{array}$ & $\begin{array}{c}0.029^{*} \\
(0.003)\end{array}$ & $\begin{array}{l}0.006^{*} \\
(0.001)\end{array}$ \\
\hline Black & $\begin{array}{c}-0.814^{*} \\
(0.04)\end{array}$ & $\begin{array}{l}0.443^{*} \\
(0.016)\end{array}$ & $\begin{array}{c}-0.057^{*} \\
(0.001)\end{array}$ & $\begin{array}{c}-0.404^{*} \\
(0.018)\end{array}$ & $\begin{array}{c}-\mathbf{0 . 0 6 1} * \\
(0.002)\end{array}$ & $\begin{array}{c}-0.841^{*} \\
(0.074)\end{array}$ & $\begin{array}{l}0.431^{*} \\
(0.032)\end{array}$ & $\begin{array}{c}-0.067^{*} \\
(0.004)\end{array}$ & $\begin{array}{c}-0.423^{*} \\
(0.036)\end{array}$ & $\begin{array}{c}-0.074^{*} \\
(0.005)\end{array}$ \\
\hline $\mathrm{A} / \mathrm{A} / \mathrm{E}$ & $\begin{array}{c}-0.20^{*} \\
(0.09)\end{array}$ & $\begin{array}{l}0.820^{*} \\
(0.08)\end{array}$ & $\begin{array}{c}-0.017^{*} \\
(0.008)\end{array}$ & $\begin{array}{c}-0.095^{*} \\
(0.048)\end{array}$ & $\begin{array}{c}-\mathbf{0 . 0 1 7} \\
(0.008)\end{array}$ & $\begin{array}{l}-0.213 \\
(0.16)\end{array}$ & $\begin{array}{c}0.808 \\
(0.129)\end{array}$ & $\begin{array}{l}-0.022 \\
(0.015)\end{array}$ & $\begin{array}{c}-0.11 \\
(0.084)\end{array}$ & $\begin{array}{l}-0.022 \\
(0.016)\end{array}$ \\
\hline Asian & $\begin{array}{l}-0.047 \\
(0.033)\end{array}$ & $\begin{array}{c}0.95 \\
(0.032)\end{array}$ & $\begin{array}{l}-0.005 \\
(0.003)\end{array}$ & $\begin{array}{l}-0.025 \\
(0.018)\end{array}$ & $\begin{array}{l}-\mathbf{0 . 0 0 5} \\
(0.003)\end{array}$ & $\begin{array}{l}-0.045 \\
(0.055)\end{array}$ & $\begin{array}{c}0.956 \\
(0.053)\end{array}$ & $\begin{array}{c}-0.006 \\
(0.006)\end{array}$ & $\begin{array}{c}-0.024 \\
(0.03)\end{array}$ & $\begin{array}{l}-0.005 \\
(0.006)\end{array}$ \\
\hline Other & $\begin{array}{l}-0.51^{*} \\
(0.147)\end{array}$ & $\begin{array}{c}0.6^{*} \\
(0.088)\end{array}$ & $\begin{array}{c}-0.044^{*} \\
(0.01)\end{array}$ & $\begin{array}{c}-0.263^{*} \\
(0.074)\end{array}$ & $\begin{array}{c}-\mathbf{0 . 0 4 2} \\
(0.01)\end{array}$ & $\begin{array}{l}-0.543 \\
(0.074)\end{array}$ & $\begin{array}{c}0.581 \\
(0.2)\end{array}$ & $\begin{array}{c}-0.051^{* *} \\
(0.026)\end{array}$ & $\begin{array}{c}-0.302^{* *} \\
(0.174)\end{array}$ & $\begin{array}{r}-0.056^{* *} \\
(0.026)\end{array}$ \\
\hline educ99 & $\begin{array}{l}0.011^{*} \\
(0.002)\end{array}$ & $\begin{array}{l}1.011^{*} \\
(0.003)\end{array}$ & $\begin{array}{c}0.002^{*} \\
(0.0003)\end{array}$ & $\begin{array}{l}0.006^{*} \\
(0.001)\end{array}$ & $\begin{array}{c}0.001^{*} \\
(0.0003)\end{array}$ & $\begin{array}{l}0.036^{*} \\
(0.004)\end{array}$ & $\begin{array}{l}1.04^{*} \\
(0.005)\end{array}$ & $\begin{array}{l}0.005^{*} \\
(0.001)\end{array}$ & $\begin{array}{c}0.019^{*} \\
(0.002)\end{array}$ & $\begin{array}{l}0.004^{*} \\
(0.001)\end{array}$ \\
\hline age & $\begin{array}{c}0.033^{*} \\
(0.003)\end{array}$ & $\begin{array}{l}1.033^{*} \\
(0.003)\end{array}$ & $\begin{array}{l}-0.003^{*} \\
(0.0003)\end{array}$ & $\begin{array}{l}0.014^{*} \\
(0.002)\end{array}$ & $\begin{array}{c}0.003^{*} \\
(0.0003)\end{array}$ & $\begin{array}{l}0.02^{*} \\
(0.005)\end{array}$ & $\begin{array}{l}1.021^{*} \\
(0.005)\end{array}$ & $\begin{array}{l}-0.006^{*} \\
(0.0007)\end{array}$ & $\begin{array}{c}0.006^{* *} \\
(0.003)\end{array}$ & $\begin{array}{l}0.001^{* *} \\
(0.001)\end{array}$ \\
\hline $\operatorname{sex}$ & $\begin{array}{c}-0.476^{*} \\
(0.012)\end{array}$ & $\begin{array}{l}0.621^{*} \\
(0.008)\end{array}$ & $\begin{array}{c}-0.049^{*} \\
(0.001)\end{array}$ & $\begin{array}{c}-0.253^{*} \\
(0.007)\end{array}$ & $\begin{array}{c}-0.048^{*} \\
(0.001)\end{array}$ & $\begin{array}{l}-0.4^{*} \\
(0.02)\end{array}$ & $\begin{array}{l}0.672^{*} \\
(0.014)\end{array}$ & $\begin{array}{c}-0.048^{*} \\
(0.002)\end{array}$ & $\begin{array}{c}-0.216^{*} \\
(0.011)\end{array}$ & $\begin{array}{c}-0.047^{*} \\
(0.002)\end{array}$ \\
\hline child & $\begin{array}{c}0.095^{*} \\
(0.006)\end{array}$ & $\begin{array}{c}1.1^{*} \\
(0.007)\end{array}$ & $\begin{array}{l}0.011^{*} \\
(0.001)\end{array}$ & $\begin{array}{l}0.053^{*} \\
(0.003)\end{array}$ & $\begin{array}{c}0.01^{*} \\
(0.001)\end{array}$ & $\begin{array}{c}0.059^{*} \\
(0.01)\end{array}$ & $\begin{array}{l}1.06^{*} \\
(0.011)\end{array}$ & $\begin{array}{c}0.008^{*} \\
(0.001)\end{array}$ & $\begin{array}{c}0.035^{*} \\
(0.006)\end{array}$ & $\begin{array}{l}0.008^{*} \\
(0.001)\end{array}$ \\
\hline cons & $\begin{array}{l}-3.24^{*} \\
(0.076)\end{array}$ & & $\begin{array}{l}0.123^{*} \\
(0.007)\end{array}$ & $\begin{array}{l}-1.75^{*} \\
(0.04)\end{array}$ & & $\begin{array}{l}-3.25 \\
(0.144)\end{array}$ & & $\begin{array}{l}0.141^{*} \\
(0.015)\end{array}$ & $\begin{array}{l}-1.73^{*} \\
(0.077)\end{array}$ & \\
\hline Marital & yes & yes & yes & yes & yes & yes & yes & yes & yes & yes \\
\hline Year & yes & yes & yes & yes & yes & yes & yes & yes & yes & yes \\
\hline
\end{tabular}

Other Controls: Marital Status, race, year,AGESQ. A/A/E American Indian/Aleut/Eskimo 


\subsection{Evidence of a Black White Entrepreneurship Gap}

Table 2 provides initial results of estimating equation 1 using probit, logit and linear probability models. Using the pre-2002 standard approach we partition the data by race into five categories; White, Black, Asian/Pacific Islander, American Indian/Eskimo/Aleut and Others. Table 2 is partitioned into two parts by wealth indicators; estimates derived using the interest income proxy and estimates using dividend income. Bearse (1984) argues that ownership of financial assets is positively correlated with the probability of entrepreneurship, therefore, a measure of wealth must be included in self-employment models. As mentioned earlier, interest income is a better proxy for wealth than dividend income given its more general coverage. However, for the purpose of robustness and examining the impact of employing more narrow definitions of wealth on self-employment probabilities we use both proxies through out the paper.

Table 2 provides evidence that our results are generally consistent with the self-employment literature. Concentrating on marginal effects estimates of the probit model, column 5 of Table 2 provides results which suggest that the probability of Black self-employment is $6.1 \%$ less than that of Whites. We also find that there is no difference in the probability of self-employment for Whites and Asians. If we use the more restrictive proxy for wealth, we find that the Black/White gap widens, which highlights the importance of wealth proxies in adequately controlling for the impact of wealth on the likelihood of self-employment.

As discussed in section 2 of this research, the literature has offered many different reasons as to why Black self-employment rates lag significantly behind that of Whites. However, there is little consensus on these reasons. There is however, an undeniable fact that for a significant period in U.S. history Blacks experienced severe social, economic, and political discrimination. Generally, there is no debate as to the existence of discrimination against African-Americans, however, the the length and breath of its' impact is still hotly contested. Could the inability of research to find answers be related to some unknown control variables that has been inadvertently omitted from most econometric work? Or has research not posed questions in ways that could lead to more informative research methodologies? This research poses the question differently in that we try to understand what could lead to differences in self-employment among comparable groups given that

\footnotetext{
${ }^{4}$ In Belton and Uwaifo (2008) arguments for why interest income makes a good proxy for saving/wealth are highlighted.

${ }^{5}$ The odds ratio are the exponentiated coefficients in an ordinary logistic regression.
} 
only their informational and institutional histories differ. To examine this issue and also highlight other interesting issues that could impact self-employment, we decompose our sample into racial subgroups and find the probability for self-employment for each of these groups. This step by step decomposition technique helps to identify not only cross-group difference but could also provide significant insights into within-group differences.

\subsection{Do Foreign Blacks and Black citizens have similar probabilities of self- employment?}

Borgan and Darity (2007) using census data from 1910 to 2000 were the first to document statistically that foreigners whether White, Asian, or Black have a higher probability of self-employment than do African-Americans. They argue that foreigners generally have more access to resources than do African-Americans. While this may be true for immigrants from newly developed countries like South Korea and Taiwan ${ }^{6}$, it is however, difficult to make such a claim for foreign Blacks, who generally migrated from Africa and/or the Caribbean, as there is little evidence pointing to significant resource accessability for these groups. In Africa and the Caribbean, levels of development and missing markets make wealth transfer and access to resources limited relative to that of countries with well developed capital markets. ${ }^{7}$

Given the trends identified by Borgan and Darity (2008) using their 1910 to 2002 data set, we examine our 1994-2002 data set to determine whether identified trends are long-lived. We decompose Black and White racial groups into seven subgroups defining the $\mathrm{R}$ matrix to include foreign Blacks (FB), Foreign Whites (FW), African Americans, American Whites, Asian, A/A/E, Other. We then re-estimate equation 1 with our newly defined $\mathrm{R}$ matrix and provide results in Table 3 . Using American Whites as the baseline group we focus on the marginal effects results in columns (5) and (10) of Table 3. Surprisingly, we find that the estimated probability of self-employment for FB is slightly higher than African-Americans (American Black), though the estimated coefficients are not statistically different. Similarly, the probability of self-employment for foreign Whites and White American citizens are similar when interest income is used as a wealth proxy. However, using

\footnotetext{
${ }^{6}$ Yoon (1997) highlights evidence for the Korean case

${ }^{7}$ We cannot make the argument that these immigrants are the urban middle class. A large number of African immigrants came in as refugees and many of those who we will typically classify as urban middle class because of educational attainment, migrated from Africa. Given the level of poverty in most of these African countries, these individuals are more likely to have been close to or below the poverty line before immigrating. Nigeria one of the countries in Africa with a sizeable number of immigrants from Africa had over $60 \%$ of its population below a $\$ 1$ poverty line in the 90 s and over $75 \%$ if a $\$ 2$ poverty line is used many of whom one would classify as urban middle class given their education levels.
} 
Table 3: Do Foreigners and Citizens have different probabilities of self-employment?

\begin{tabular}{|c|c|c|c|c|c|c|c|c|c|c|}
\hline \multirow{2}{*}{ Variable: } & \multicolumn{5}{|c|}{ Saving Indicator 1} & \multicolumn{5}{|c|}{ Savings Indicator 2} \\
\hline & $\begin{array}{c}\operatorname{logit} \\
(1)\end{array}$ & $\begin{array}{c}\text { logistic } \\
(2)\end{array}$ & $\begin{array}{c}\text { Linear } \\
(3)\end{array}$ & $\begin{array}{c}\text { Probit } \\
(4)\end{array}$ & $\begin{array}{c}\text { dprobit } \\
(5)\end{array}$ & $\begin{array}{c}\operatorname{logit} \\
(6)\end{array}$ & $\begin{array}{c}\text { logistic } \\
(7)\end{array}$ & $\begin{array}{c}\text { Linear } \\
(8)\end{array}$ & $\begin{array}{c}\text { Probit } \\
(9)\end{array}$ & $\begin{array}{c}\text { dprobit } \\
(10)\end{array}$ \\
\hline logincint & $\begin{array}{l}0.095^{*} \\
(0.003)\end{array}$ & $\begin{array}{c}1.1^{*} \\
(0.003)\end{array}$ & $\begin{array}{c}0.010^{*} \\
(0.0003)\end{array}$ & $\begin{array}{c}0.05^{*} \\
(0.002)\end{array}$ & $\begin{array}{c}0.009^{*} \\
(0.0003)\end{array}$ & & & & & \\
\hline logdefincdiv & & & & & & $\begin{array}{l}0.054^{*} \\
(0.005)\end{array}$ & $\begin{array}{c}1.055^{*} \\
(0.005)\end{array}$ & $\begin{array}{l}0.006^{*} \\
(0.001)\end{array}$ & $\begin{array}{c}0.029^{*} \\
(0.003)\end{array}$ & $\begin{array}{l}0.007^{*} \\
(0.001)\end{array}$ \\
\hline Foreign Black & $\begin{array}{c}-0.602^{*} \\
(0.148)\end{array}$ & $\begin{array}{l}0.548^{*} \\
(0.081)\end{array}$ & $\begin{array}{c}-0.042^{*} \\
(0.008)\end{array}$ & $\begin{array}{c}-0.304^{*} \\
(0.072)\end{array}$ & $\begin{array}{c}-\mathbf{0 . 0 4 7} \\
(0.009)\end{array}$ & $\begin{array}{c}-0.802^{*} \\
(0.36)\end{array}$ & $\begin{array}{c}0.448^{*} \\
(0.161)\end{array}$ & $\begin{array}{c}-0.057^{*} \\
(0.019)\end{array}$ & $\begin{array}{c}-0.439^{*} \\
(0.171)\end{array}$ & $\begin{array}{c}-0.074^{*} \\
(0.021)\end{array}$ \\
\hline Foreign White & $\begin{array}{c}0.054 \\
(0.038)\end{array}$ & $\begin{array}{l}1.056 \\
(0.04)\end{array}$ & $\begin{array}{c}0.004 \\
(0.004)\end{array}$ & $\begin{array}{c}0.027 \\
(0.020)\end{array}$ & $\begin{array}{c}\mathbf{0 . 0 0 5} \\
(0.004)\end{array}$ & $\begin{array}{l}0.212^{*} \\
(0.079)\end{array}$ & $\begin{array}{l}1.24^{*} \\
(0.097)\end{array}$ & $\begin{array}{c}0.026^{*} \\
(0.01)\end{array}$ & $\begin{array}{c}0.114^{*} \\
(0.043)\end{array}$ & $\begin{array}{l}0.026^{*} \\
(0.011)\end{array}$ \\
\hline Black Citizens & $\begin{array}{c}-0.823^{*} \\
(0.038)\end{array}$ & $\begin{array}{l}0.439^{*} \\
(0.017)\end{array}$ & $\begin{array}{c}-0.056^{*} \\
(0.002)\end{array}$ & $\begin{array}{c}-0.408^{*} \\
(0.018)\end{array}$ & $\begin{array}{c}-\mathbf{0 . 0 6 1} * \\
(0.002)\end{array}$ & $\begin{array}{l}-0.838^{*} \\
(0.075)\end{array}$ & $\begin{array}{c}0.433^{*} \\
(0.033)\end{array}$ & $\begin{array}{c}-0.066^{*} \\
(0.004)\end{array}$ & $\begin{array}{l}-0.42^{*} \\
(0.037)\end{array}$ & $\begin{array}{c}-0.074^{*} \\
(0.005)\end{array}$ \\
\hline $\mathrm{A} / \mathrm{A} / \mathrm{E}$ & $\begin{array}{c}-0.197^{*} \\
(0.092)\end{array}$ & $\begin{array}{c}0.821^{*} \\
(0.076)\end{array}$ & $\begin{array}{c}-0.017^{*} \\
(0.008)\end{array}$ & $\begin{array}{c}-0.094^{*} \\
(0.048)\end{array}$ & $\begin{array}{c}-\mathbf{0 . 0 1 7} \\
(0.008)\end{array}$ & $\begin{array}{l}-0.21 \\
(0.16)\end{array}$ & $\begin{array}{c}0.81 \\
(0.129)\end{array}$ & $\begin{array}{l}-0.022 \\
(0.015)\end{array}$ & $\begin{array}{c}-0.10 \\
(0.084)\end{array}$ & $\begin{array}{c}-0.022 \\
(0.016)\end{array}$ \\
\hline Asian & $\begin{array}{l}-0.045 \\
(0.033)\end{array}$ & $\begin{array}{c}0.956 \\
(0.032)\end{array}$ & $\begin{array}{c}-0.005 \\
(0.003)\end{array}$ & $\begin{array}{l}-0.025 \\
(0.018)\end{array}$ & $\begin{array}{r}-\mathbf{0 . 0 0 5} \\
(0.003)\end{array}$ & $\begin{array}{l}-0.041 \\
(0.055)\end{array}$ & $\begin{array}{c}0.96 \\
(0.053)\end{array}$ & $\begin{array}{l}-0.005 \\
(0.006)\end{array}$ & $\begin{array}{c}-0.022 \\
(0.03)\end{array}$ & $\begin{array}{l}-0.005 \\
(0.006)\end{array}$ \\
\hline Other & $\begin{array}{l}-0.508^{*} \\
(0.147)\end{array}$ & $\begin{array}{l}0.602^{*} \\
(0.088)\end{array}$ & $\begin{array}{c}-0.044^{*} \\
(0.01)\end{array}$ & $\begin{array}{c}-0.262^{*} \\
(0.074)\end{array}$ & $\begin{array}{c}-\mathbf{- 0 . 0 4 2}^{*} \\
(0.01)\end{array}$ & $\begin{array}{l}-0.55 \\
(0.344)\end{array}$ & $\begin{array}{c}0.583 \\
(0.2)\end{array}$ & $\begin{array}{c}-0.051^{* *} \\
(0.026)\end{array}$ & $\begin{array}{l}-0.3^{* *} \\
(0.174)\end{array}$ & $\begin{array}{r}-0.055^{* *} \\
(0.026)\end{array}$ \\
\hline educ99 & $\begin{array}{l}0.011^{*} \\
(0.003)\end{array}$ & $\begin{array}{l}1.011^{*} \\
(0.003)\end{array}$ & $\begin{array}{c}0.002^{*} \\
(0.0003)\end{array}$ & $\begin{array}{c}0.006^{*} \\
(0.001)\end{array}$ & $\begin{array}{c}0.001^{*} \\
(0.0002)\end{array}$ & $\begin{array}{l}0.036^{*} \\
(0.004)\end{array}$ & $\begin{array}{c}1.037^{*} \\
(0.005)\end{array}$ & $\begin{array}{l}0.005^{*} \\
(0.001)\end{array}$ & $\begin{array}{c}0.019^{*} \\
(0.002)\end{array}$ & $\begin{array}{l}0.004^{*} \\
(0.001)\end{array}$ \\
\hline age & $\begin{array}{l}0.033^{*} \\
(0.003)\end{array}$ & $\begin{array}{c}1.03^{*} \\
(0.003)\end{array}$ & $\begin{array}{c}-0.003^{*} \\
(0.0003)\end{array}$ & $\begin{array}{l}0.014^{*} \\
(0.002)\end{array}$ & $\begin{array}{c}0.003^{*} \\
(0.0003)\end{array}$ & $\begin{array}{c}0.02^{*} \\
(0.005)\end{array}$ & $\begin{array}{c}1.02 * \\
(0.005)\end{array}$ & $\begin{array}{c}-0.006^{*} \\
(0.007)\end{array}$ & $\begin{array}{c}0.006^{* *} \\
(0.003)\end{array}$ & $\begin{array}{c}0.001^{* *} \\
(0.001)\end{array}$ \\
\hline & 10.95 & 10.95 & -9.65 & 8.65 & 8.65 & 3.82 & 3.82 & -8.93 & 1.93 & 1.93 \\
\hline sex & $\begin{array}{l}-0.48^{*} \\
(0.012)\end{array}$ & $\begin{array}{c}0.621^{*} \\
(0.008)\end{array}$ & $\begin{array}{c}-0.049^{*} \\
(0.001)\end{array}$ & $\begin{array}{c}-0.253^{*} \\
(0.007)\end{array}$ & $\begin{array}{c}-0.048^{*} \\
(0.001)\end{array}$ & $\begin{array}{c}-0.396^{*} \\
(0.02)\end{array}$ & $\begin{array}{c}0.673^{*} \\
(0.014)\end{array}$ & $\begin{array}{c}-0.048^{*} \\
(0.002)\end{array}$ & $\begin{array}{c}-0.215^{*} \\
(0.011)\end{array}$ & $\begin{array}{c}-0.047^{*} \\
(0.002)\end{array}$ \\
\hline child & $\begin{array}{l}0.095^{*} \\
(0.006)\end{array}$ & $\begin{array}{l}1.099^{*} \\
(0.007)\end{array}$ & $\begin{array}{l}0.011^{*} \\
(0.001)\end{array}$ & $\begin{array}{c}0.053^{*} \\
(0.003)\end{array}$ & $\begin{array}{c}0.01^{*} \\
(0.001)\end{array}$ & $\begin{array}{c}0.059^{*} \\
(0.01)\end{array}$ & $\begin{array}{l}1.06^{*} \\
(0.01)\end{array}$ & $\begin{array}{l}0.008^{*} \\
(0.001)\end{array}$ & $\begin{array}{c}0.035^{*} \\
(0.006)\end{array}$ & $\begin{array}{l}0.008^{*} \\
(0.001)\end{array}$ \\
\hline cons & $\begin{array}{l}-3.25^{*} \\
(0.076)\end{array}$ & & $\begin{array}{l}0.123^{*} \\
(0.007)\end{array}$ & $\begin{array}{c}-1.76^{*} \\
(0.04)\end{array}$ & & $\begin{array}{l}-3.25^{*} \\
(0.143)\end{array}$ & & $\begin{array}{c}0.14^{*} \\
(0.015)\end{array}$ & $\begin{array}{l}-1.74^{*} \\
(0.077)\end{array}$ & \\
\hline marst & yes & yes & yes & yes & yes & yes & yes & yes & yes & yes \\
\hline year & yes & yes & yes & yes & yes & yes & yes & yes & yes & yes \\
\hline region & no & no & no & no & no & no & no & no & no & no \\
\hline cohort & no & no & no & no & no & no & no & no & no & no \\
\hline metro & no & no & no & no & no & no & no & no & no & no \\
\hline
\end{tabular}

Other Controls: Marital Status, race, year, AGEsq. A/A/E American Indian/Aleut/Eskimo AA-African Americans * 5\% significance ${ }^{* *} 10 \%$ significance 
dividend income as a wealth proxy, results in Table 3 suggests that foreign Whites have a higher probability of self-employment relative to White Americans. This difference in results again reveals the impact of using dividend income as a proxy for wealth.

For Blacks the results from Table 3 do not confirm those of Borgan and Darity (2008) with regards to foreign Blacks having higher self-employment probabilities than do American Blacks and could reflect recent changes the choices to enter the ranks of the self-employed for these groups. However, we do find that foreign Blacks and Black American citizens have a significantly lower probability of self-employment than do Whites. The results from Table 3 raise two issues: First, we argue above that not all Blacks in America have been exposed to the same information matrix over time which should lead to significantly different self-employment choices across sub-groups. Clearly, FB and African-Americans derive from different informational regimes but according to results in Table 3 tend to pursue self-employment similarly. We also find that foreign Whites FW have a greater probability of self-employment than do foreign Blacks, primarily suggesting a role for racial discrimination. The results for FB and African-Americans could have little to do with discrimination and can be explained by two separate factors attenuating the probability of self-employment for both groups. In particular, African-American lower probability of self-employment could be related to their unique information matrix discussed above where as institutional and economic barriers could explain low probabilities for FB. We explore these questions further in the sections that follow.

\subsection{Does Probability of self-employment differ across immigrants from devel- oped countries versus developing countries?}

Issues raised in the previous section lead us to question the impact of the economic standing of the immigrant's country of origin on the decision to pursue self-employment for both White and Black foreigners. This question is relevant because differences in self-employment probabilities between foreign Blacks and Whites may be a result of economic resource constraints and not racial and/or social discrimination. ${ }^{8}$ Decomposing foreigners by the level of development in their country of origin was first highlighted in Belton and Oyelere (2008). They argue that comparable Whites from developed and and less developed countries save differently in the U.S., therefore, treating them as one group could lead to biased inferences. Moreover, Bogan and Darity (2008) highlight the

\footnotetext{
${ }^{8}$ Social discrimination is define as the the existence of laws and rules that make it difficult for foreigners to find employment in the formal sector because they lack specific documentation, do not have educational qualifications obtained in the U.S., or have a strong accent or language limitation.
} 
Table 4: LDC vs DC and Self-Employment Gap

\begin{tabular}{|c|c|c|c|c|c|c|c|c|c|c|}
\hline \multirow[t]{2}{*}{ Variable: } & \multicolumn{5}{|c|}{ Wealth Indicator 1} & \multicolumn{5}{|c|}{ Wealth Indicator 2} \\
\hline & $\begin{array}{l}\operatorname{logit} \\
(1)\end{array}$ & $\begin{array}{c}\text { logistic } \\
(2)\end{array}$ & $\begin{array}{c}\text { Linear } \\
(3)\end{array}$ & $\begin{array}{c}\text { Probit } \\
(4)\end{array}$ & $\begin{array}{c}\text { dprobit } \\
(5)\end{array}$ & $\begin{array}{c}\operatorname{logit} \\
(6)\end{array}$ & $\begin{array}{c}\text { logistic } \\
(7)\end{array}$ & $\begin{array}{c}\text { Linear } \\
(8)\end{array}$ & $\begin{array}{c}\text { Probit } \\
(9)\end{array}$ & $\begin{array}{c}\text { dprobit } \\
(10)\end{array}$ \\
\hline & 1 & 2 & 3 & 4 & 5 & 6 & 7 & 8 & 9 & 10 \\
\hline logincint & $\begin{array}{c}0.095^{*} \\
(0.003)\end{array}$ & $\begin{array}{l}1.099^{*} \\
(0.003)\end{array}$ & $\begin{array}{c}0.01 * \\
(0.0003)\end{array}$ & $\begin{array}{c}0.05^{*} \\
(0.002)\end{array}$ & $\begin{array}{c}0.009 * \\
(0.0003)\end{array}$ & & & & & \\
\hline logdefincdiv & & & & & & $\begin{array}{l}0.054^{*} \\
(0.005)\end{array}$ & $\begin{array}{l}1.06^{*} \\
(0.005)\end{array}$ & $\begin{array}{c}0.007^{*} \\
(0.001)\end{array}$ & $\begin{array}{c}0.029 * \\
(0.003)\end{array}$ & $\begin{array}{c}0.006 \\
(0.0\end{array}$ \\
\hline Foreign Black & $\begin{array}{c}-0.603^{*} \\
(0.148)\end{array}$ & $\begin{array}{l}0.547^{*} \\
(0.081)\end{array}$ & $\begin{array}{c}-0.042^{*} \\
(0.008)\end{array}$ & $\begin{array}{c}-0.304^{*} \\
(0.072)\end{array}$ & $\begin{array}{c}-\mathbf{0 . 0 4 7} \\
(0.009)\end{array}$ & $\begin{array}{c}-0.803^{*} \\
(0.397)\end{array}$ & $\begin{array}{l}0.448^{*} \\
(0.161)\end{array}$ & $\begin{array}{c}-0.057^{*} \\
(0.019)\end{array}$ & $\begin{array}{c}-0.439^{*} \\
(0.171)\end{array}$ & $\begin{array}{c}-0.074^{*} \\
(0.021)\end{array}$ \\
\hline FWLDC & $\begin{array}{c}-0.103^{*} \\
(0.047)\end{array}$ & $\begin{array}{l}0.902^{*} \\
(0.042)\end{array}$ & $\begin{array}{c}-0.001^{*} \\
(0.004)\end{array}$ & $\begin{array}{c}-0.053^{*} \\
(0.024)\end{array}$ & $\begin{array}{c}-\mathbf{0 . 0 0 1} * \\
(0.004)\end{array}$ & $\begin{array}{c}0.041 \\
(0.118)\end{array}$ & $\begin{array}{c}1.04 \\
(0.123)\end{array}$ & $\begin{array}{c}0.005 \\
(0.013)\end{array}$ & $\begin{array}{c}0.024 \\
(0.063)\end{array}$ & $\begin{array}{c}0.005 \\
(0.014)\end{array}$ \\
\hline FWDC & $\begin{array}{c}0.303^{*} \\
(0.061)\end{array}$ & $\begin{array}{l}1.35^{*} \\
(0.082)\end{array}$ & $\begin{array}{c}0.035^{*} \\
(0.008)\end{array}$ & $\begin{array}{c}0.163^{*} \\
(0.034)\end{array}$ & $\begin{array}{c}\mathbf{0 . 0 3 4} \boldsymbol{*} \\
(0.008)\end{array}$ & $\begin{array}{l}0.331^{*} \\
(0.104)\end{array}$ & $\begin{array}{l}1.39^{*} \\
(0.145)\end{array}$ & $\begin{array}{l}0.044^{*} \\
(0.015)\end{array}$ & $\begin{array}{c}0.18^{*} \\
(0.059)\end{array}$ & $\begin{array}{c}0.043^{*} \\
(0.0153)\end{array}$ \\
\hline Black Citizen & $\begin{array}{c}-0.824^{*} \\
(0.038)\end{array}$ & $\begin{array}{l}0.439^{*} \\
(0.017)\end{array}$ & $\begin{array}{c}-0.058^{*} \\
(0.002)\end{array}$ & $\begin{array}{c}-0.408^{*} \\
(0.018)\end{array}$ & $\begin{array}{c}-\mathbf{0 . 0 6 1} \\
(0.002)\end{array}$ & $\begin{array}{c}-0.838^{*} \\
(0.075)\end{array}$ & $\begin{array}{c}0.432^{*} \\
(0.0326)\end{array}$ & $\begin{array}{c}-0.067^{*} \\
(0.004)\end{array}$ & $\begin{array}{l}-0.42^{*} \\
(0.037)\end{array}$ & $\begin{array}{c}-0.074^{*} \\
(0.005)\end{array}$ \\
\hline $\mathrm{A} / \mathrm{A} / \mathrm{E}$ & $\begin{array}{c}-0.198^{*} \\
(0.092)\end{array}$ & $\begin{array}{c}0.82^{*} \\
(0.076)\end{array}$ & $\begin{array}{c}-0.017^{*} \\
(0.008)\end{array}$ & $\begin{array}{c}-0.095^{*} \\
(0.048)\end{array}$ & $\begin{array}{c}-\mathbf{0 . 0 1 7} \\
(0.008)\end{array}$ & $\begin{array}{l}-0.21 \\
(0.159)\end{array}$ & $\begin{array}{c}0.811 \\
(0.129)\end{array}$ & $\begin{array}{l}-0.022 \\
(0.015)\end{array}$ & $\begin{array}{l}-0.104 \\
(0.084)\end{array}$ & $\begin{array}{l}-0.022 \\
(0.016)\end{array}$ \\
\hline Asia & $\begin{array}{l}-0.045 \\
(0.033)\end{array}$ & $\begin{array}{c}0.956 \\
(0.032)\end{array}$ & $\begin{array}{l}-0.005 \\
(0.003)\end{array}$ & $\begin{array}{l}-0.025 \\
(0.018)\end{array}$ & $\begin{array}{c}-\mathbf{0 . 0 0 5} \\
(0.003)\end{array}$ & $\begin{array}{c}-0.0412 \\
(0.055)\end{array}$ & $\begin{array}{c}0.96 \\
(0.053)\end{array}$ & $\begin{array}{c}-0.005 \\
(0.0064)\end{array}$ & $\begin{array}{c}-0.022 \\
(0.03)\end{array}$ & $\begin{array}{l}-0.005 \\
(0.006)\end{array}$ \\
\hline Other & $\begin{array}{c}-0.510^{*} \\
(0.147)\end{array}$ & $\begin{array}{c}0.6^{*} \\
(0.088)\end{array}$ & $\begin{array}{c}-0.044^{*} \\
(0.01)\end{array}$ & $\begin{array}{r}-0.263^{*} \\
(0.074)\end{array}$ & $\begin{array}{c}-\mathbf{0 . 0 4 2} \\
(0.01)\end{array}$ & $\begin{array}{l}-0.54 \\
(0.344)\end{array}$ & $\begin{array}{c}0.582 \\
(0.2)\end{array}$ & $\begin{array}{c}-0.051^{* *} \\
(0.026)\end{array}$ & $\begin{array}{l}-0.3^{* *} \\
(0.174)\end{array}$ & $\begin{array}{c}-0.055^{* *} \\
(0.026)\end{array}$ \\
\hline educ99 & $\begin{array}{l}0.011^{*} \\
(0.003)\end{array}$ & $\begin{array}{l}1.01^{*} \\
(0.003)\end{array}$ & $\begin{array}{c}0.002^{*} \\
(0.0003)\end{array}$ & $\begin{array}{l}0.005^{*} \\
(0.001)\end{array}$ & $\begin{array}{c}0.001^{*} \\
(0.0002)\end{array}$ & $\begin{array}{l}0.036^{*} \\
(0.004)\end{array}$ & $\begin{array}{l}1.036^{*} \\
(0.005)\end{array}$ & $\begin{array}{l}0.005^{*} \\
(0.001)\end{array}$ & $\begin{array}{l}0.019^{*} \\
(0.002)\end{array}$ & $\begin{array}{l}0.004^{*} \\
(0.001)\end{array}$ \\
\hline Age & $\begin{array}{l}0.033^{*} \\
(0.003)\end{array}$ & $\begin{array}{l}1.033^{*} \\
(0.003)\end{array}$ & $\begin{array}{l}-0.003^{*} \\
(0.0003)\end{array}$ & $\begin{array}{c}0.014^{*} \\
(0.002)\end{array}$ & $\begin{array}{c}0.003^{*} \\
(0.0003)\end{array}$ & $\begin{array}{l}0.02 * \\
(0.005)\end{array}$ & $\begin{array}{l}1.02^{*} \\
(0.005)\end{array}$ & $\begin{array}{c}-0.006^{*} \\
(0.001)\end{array}$ & $\begin{array}{c}0.006^{* *} \\
(0.003)\end{array}$ & $\begin{array}{c}0.001^{* *} \\
(0.001)\end{array}$ \\
\hline sex & $\begin{array}{c}-0.477^{*} \\
(0.012)\end{array}$ & $\begin{array}{l}0.62^{*} \\
(0.008)\end{array}$ & $\begin{array}{c}-0.049^{*} \\
(0.001)\end{array}$ & $\begin{array}{c}-0.253^{*} \\
(0.007)\end{array}$ & $\begin{array}{c}-0.048^{*} \\
(0.001)\end{array}$ & $\begin{array}{l}-0.40^{*} \\
(0.02)\end{array}$ & $\begin{array}{l}0.673^{*} \\
(0.014)\end{array}$ & $\begin{array}{c}-0.048^{*} \\
(0.002)\end{array}$ & $\begin{array}{l}-0.22^{*} \\
(0.011)\end{array}$ & $\begin{array}{c}-0.047^{*} \\
(0.002)\end{array}$ \\
\hline Child & $\begin{array}{c}0.096^{*} \\
(0.006)\end{array}$ & $\begin{array}{l}1.10^{*} \\
(0.007)\end{array}$ & $\begin{array}{l}0.011^{*} \\
(0.001)\end{array}$ & $\begin{array}{l}0.053^{*} \\
(0.003)\end{array}$ & $\begin{array}{c}0.01^{*} \\
(0.001)\end{array}$ & $\begin{array}{l}0.059^{*} \\
(0.01)\end{array}$ & $\begin{array}{l}1.06^{*} \\
(0.011)\end{array}$ & $\begin{array}{l}0.008^{*} \\
(0.001)\end{array}$ & $\begin{array}{c}0.035^{*} \\
(0.006)\end{array}$ & $\begin{array}{l}0.008^{*} \\
(0.001)\end{array}$ \\
\hline cons & $\begin{array}{c}-3.23^{*} \\
(0.076)\end{array}$ & & $\begin{array}{l}0.125^{*} \\
(0.007)\end{array}$ & $\begin{array}{c}-1.75^{*} \\
(0.04)\end{array}$ & & $\begin{array}{l}-3.25^{*} \\
(0.144)\end{array}$ & & $\begin{array}{c}0.14^{*} \\
(0.015)\end{array}$ & $\begin{array}{l}-1.74^{*} \\
(0.077)\end{array}$ & \\
\hline marst & yes & yes & yes & yes & yes & yes & yes & yes & yes & yes \\
\hline year & yes & yes & yes & yes & yes & yes & yes & yes & yes & yes \\
\hline region & no & no & no & no & no & no & no & no & no & no \\
\hline cohort & no & no & no & no & no & no & no & no & no & no \\
\hline metro & no & no & no & no & no & no & no & no & no & no \\
\hline
\end{tabular}

Other Controls: Marital Status, race, year,AGESQ. A/A/E American Indian/Aleut/Eskimo

* $5 \%$ significance $* * 10 \%$ siignifcance 
resource availability issue in self-employment decision, arguing that many immigrants have assess to resources from their home country making self-employment success more likely. We believe that resource endowments differ across developed and less developed countries as foreigners from developing countries are less likely to have tangible capital resources and assets that can transfer to the U.S. than do those from developed countries. Hence, if resource availability affects entry into self-employment, then according to the Bogan and Darity (2008) argument, foreigners from less developed countries should have a lower probability of self-employment than those from developed countries. We again alter the $\mathrm{R}$ matrix to reflect differences in the economic status of the home country for White immigrants where foreign Whites are divided into those from developed countries and those from developing countries. ${ }^{9}$

Focusing on columns (5) of Table 4, using interest income as the wealth proxy, we find that foreign Whites from developed countries (FWDC) have a 3.4\% higher probability of self-employment than do White Americans, whereas foreign Whites from less developed countries (FWLDC)have a (0.1\%) lower probability of self-employment than do White Americans. This is an interesting result and may highlight the importance of external capital and other resources not captured by wealth proxies in the decision to enter self-employment. Using dividend income as a wealth proxy, column(10), we get slightly different results. FWLDC have an equal probability of self-employment to that of White American citizens, but have a higher probability of self-employment than do FB who are also from less developed countries. This results may suggest that external resources may not be the only factor affecting the self-employment decision. Racial discrimination may play a significant role in explaining why FB, who are generally from less developed countries, have significantly lower probability of self-employment than do FWLDC, though both face similar potential capital/resource constraints.

Another potential argument which could explain the gap is discrimination on the bases of language, i.e., differences in self-employment probabilities among foreigners may depend on their command of the English language. In a related paper Oyelere and Belton (2008) explore this argument and find that command of the English language as measured by the official language of the home country does not impact self-employment probabilities for FW but has a significant impact on FB self-employment probabilities. This finding suggests the gap is more likely to be driven by racial or

\footnotetext{
${ }^{9}$ We do not divide Blacks into those from LDCs and DC because a nonsignificant number of Blacks immigrate from DC's
} 
accent discrimination rather than ability to speak English.

\subsection{Does becoming a US citizen affect the probability of self-employment?}

Given that foreigners have several restriction that could reduce their opportunities in the formal labor market including visa restrictions, jobs that require U.S. citizenship, firms' preferences for U.S. trained college graduates, and in some cases language constraint, it may be useful to examine the impact of citizenship on self-employment probabilities of immigrants to the U.S. The language constraints has two dimensions, the inability to speak English fluently and for those who speak fluently there is the accent constraint. Given these institutional and immigration constraints, foreigners may be forced into the informal sector and/or self-employment. If these constraints are binding, then naturalization should reduce the impact of the formal institutional barriers, but would have little impact on the informal barriers such as language and accent. To examine these issues, we again decompose our sample and create dummy variables for naturalized Blacks and Whites. We estimate equation 1 using our four different probability models, two different wealth proxies, and nine dummy variables including FWLDC, FWDC, FB, Naturalized American Blacks (NAB), Naturalized American Whites (NAW), U.S. born Blacks, U.S. born Whites, Asian, A/A/E and Others. The results in Table 5 reveals that NAW have a $1.7 \%$ higher probability of self-employment than do U.S. born Whites but a lower probability of self-employment than FWDC. However, FWLDC have a lower probability of self-employment than do NAW. These result may provide suggestive evidence that as individuals transition fully into the U.S., through citizenship, their probability of self-employment is reduced as more formal labor market opportunities become available. In contrast, NAB have a lower probability of self-employment than U.S born Whites, they are more likely to be self-employed than FB. These contrasting results highlight some of the difficulty in understanding transitions into and out of self-employment. In addition, results show that the impact of citizenship on the self-employment decision could be race dependent. However, we continue to find as in most of the literature that U.S born Blacks generally maintain the lowest probability of self-employment among all subgroups. Lagging self-employment probabilities for African-Americans and attempting to understand the rationale for this gap leads to our primary identification strategy. 
Table 5: Does being Born in the U.S. matter for the Self-Employment Gap?

\begin{tabular}{|c|c|c|c|c|c|c|c|c|c|c|}
\hline \multirow[t]{2}{*}{ Variable: } & \multicolumn{5}{|c|}{ Saving Indicator 1} & \multicolumn{5}{|c|}{ Savings Indicator 2} \\
\hline & $\begin{array}{c}\operatorname{logit} \\
(1)\end{array}$ & $\begin{array}{c}\text { logistic } \\
(2)\end{array}$ & $\begin{array}{c}\text { Linear } \\
(3)\end{array}$ & $\begin{array}{c}\text { Probit } \\
(4)\end{array}$ & $\begin{array}{c}\text { dprobit } \\
(5)\end{array}$ & $\begin{array}{c}\operatorname{logit} \\
(6)\end{array}$ & $\begin{array}{c}\text { logistic } \\
(7)\end{array}$ & $\begin{array}{c}\text { Linear } \\
(8)\end{array}$ & $\begin{array}{c}\text { Probit } \\
(9)\end{array}$ & $\begin{array}{c}\text { dprobit } \\
(10)\end{array}$ \\
\hline & 1 & 2 & 3 & 4 & 5 & 6 & 7 & 8 & 9 & 10 \\
\hline $\operatorname{logincint}$ & $\begin{array}{l}0.095^{*} \\
(0.003)\end{array}$ & $\begin{array}{c}1.1^{*} \\
(0.003)\end{array}$ & $\begin{array}{c}0.01^{*} \\
(0.0003)\end{array}$ & $\begin{array}{c}0.05^{*} \\
(0.002)\end{array}$ & $\begin{array}{c}0.01^{*} \\
(0.0003)\end{array}$ & & & & & \\
\hline logincdiv & & & & & & $\begin{array}{c}0.054^{*} \\
(0.005)\end{array}$ & $\begin{array}{l}1.06^{*} \\
(0.005)\end{array}$ & $\begin{array}{c}0.007^{*} \\
(0.001)\end{array}$ & $\begin{array}{c}0.029^{*} \\
(0.0027)\end{array}$ & $\begin{array}{l}0.006^{*} \\
(0.001)\end{array}$ \\
\hline FB & $\begin{array}{c}-0.598^{*} \\
(0.148)\end{array}$ & $\begin{array}{l}0.55^{*} \\
(0.081)\end{array}$ & $\begin{array}{c}-0.042^{*} \\
(0.008)\end{array}$ & $\begin{array}{c}-0.301^{*} \\
(0.072)\end{array}$ & $\begin{array}{c}-\mathbf{0 . 0 4 7} \\
(0.009)\end{array}$ & $\begin{array}{c}-0.798^{*} \\
(0.356)\end{array}$ & $\begin{array}{l}0.45^{*} \\
(0.162)\end{array}$ & $\begin{array}{c}-0.056^{*} \\
(0.019)\end{array}$ & $\begin{array}{c}-0.436^{*} \\
(0.171)\end{array}$ & $\begin{array}{c}-0.074^{*} \\
(0.021)\end{array}$ \\
\hline FWLDC & $\begin{array}{l}-0.098^{*} \\
(0.047)\end{array}$ & $\begin{array}{l}0.906^{*} \\
(0.043)\end{array}$ & $\begin{array}{c}-0.009^{*} \\
(0.004)\end{array}$ & $\begin{array}{c}-0.045^{*} \\
(0.024)\end{array}$ & $\begin{array}{c}-\mathbf{0 . 0 0 9 *} \\
(0.004)\end{array}$ & $\begin{array}{c}0.046 \\
(0.118)\end{array}$ & $\begin{array}{c}1.047 \\
(0.124)\end{array}$ & $\begin{array}{c}0.005 \\
(0.013)\end{array}$ & $\begin{array}{c}0.027 \\
(0.063)\end{array}$ & $\begin{array}{c}0.006 \\
(0.014)\end{array}$ \\
\hline FWDC & $\begin{array}{l}0.308^{*} \\
(0.061)\end{array}$ & $\begin{array}{l}1.36^{*} \\
(0.082)\end{array}$ & $\begin{array}{c}0.036^{*} \\
(0.008)\end{array}$ & $\begin{array}{l}0.165^{*} \\
(0.034)\end{array}$ & $\begin{array}{l}\mathbf{0 . 0 3 4 *} \\
(0.008)\end{array}$ & $\begin{array}{c}0.336^{*} \\
(0.104)\end{array}$ & $\begin{array}{c}1.4^{*} \\
(0.145)\end{array}$ & $\begin{array}{l}0.044^{*} \\
(0.015)\end{array}$ & $\begin{array}{c}0.183^{*} \\
(0.058)\end{array}$ & $\begin{array}{l}0.044^{*} \\
(0.015)\end{array}$ \\
\hline Black & $\begin{array}{l}-0.843^{*} \\
(0.039)\end{array}$ & $\begin{array}{l}0.43^{*} \\
(0.017)\end{array}$ & $\begin{array}{c}-0.058^{*} \\
(0.002)\end{array}$ & $\begin{array}{c}-0.416^{*} \\
(0.019)\end{array}$ & $\begin{array}{c}-\mathbf{0 . 0 6 2} \\
(0.002)\end{array}$ & $\begin{array}{l}-0.87^{*} \\
(0.079)\end{array}$ & $\begin{array}{l}0.419^{*} \\
(0.033)\end{array}$ & $\begin{array}{c}-0.068^{*} \\
(0.005)\end{array}$ & $\begin{array}{c}-0.436^{*} \\
(0.038)\end{array}$ & $\begin{array}{l}-0.075^{*} \\
(0.005)\end{array}$ \\
\hline NAW & $\begin{array}{l}0.153^{*} \\
(0.033)\end{array}$ & $\begin{array}{l}1.166^{*} \\
(0.038)\end{array}$ & $\begin{array}{l}0.021^{*} \\
(0.005)\end{array}$ & $\begin{array}{c}0.086^{*} \\
(0.0183)\end{array}$ & $\begin{array}{l}\mathbf{0 . 0 1 7} * \\
(0.004)\end{array}$ & $\begin{array}{c}0.174^{*} \\
(0.057)\end{array}$ & $\begin{array}{l}1.19 * \\
(0.068)\end{array}$ & $\begin{array}{l}0.026^{*} \\
(0.009)\end{array}$ & $\begin{array}{l}0.104^{*} \\
(0.033)\end{array}$ & $\begin{array}{l}0.024^{*} \\
(0.008)\end{array}$ \\
\hline NAB & $\begin{array}{c}-0.478^{*} \\
(0.133)\end{array}$ & $\begin{array}{c}0.62^{*} \\
(0.082)\end{array}$ & $\begin{array}{c}-0.043^{*} \\
(0.01)\end{array}$ & $\begin{array}{c}-0.251^{*} \\
(0.068)\end{array}$ & $\begin{array}{c}-\mathbf{0 . 0 4 0 2} \\
(0.009)\end{array}$ & $\begin{array}{l}-0.368 \\
(0.257)\end{array}$ & $\begin{array}{c}0.692 \\
(0.178)\end{array}$ & $\begin{array}{l}-0.036 \\
(0.023)\end{array}$ & $\begin{array}{c}-0.178 \\
(0.135)\end{array}$ & $\begin{array}{l}-0.035 \\
(0.024)\end{array}$ \\
\hline $\mathrm{A} / \mathrm{A} / \mathrm{E}$ & $\begin{array}{l}-0.193^{*} \\
(0.092)\end{array}$ & $\begin{array}{l}0.825^{*} \\
(0.076)\end{array}$ & $\begin{array}{c}-0.016^{*} \\
(0.008)\end{array}$ & $\begin{array}{c}-0.092^{* *} \\
(0.048)\end{array}$ & $\begin{array}{c}-\mathbf{0 . 0 1 6}^{* *} \\
(0.008)\end{array}$ & $\begin{array}{l}-0.205 \\
(0.159)\end{array}$ & $\begin{array}{l}0.814 \\
(0.13)\end{array}$ & $\begin{array}{l}-0.021 \\
(0.015)\end{array}$ & $\begin{array}{l}-0.102 \\
(0.084)\end{array}$ & $\begin{array}{l}-0.021 \\
(0.016)\end{array}$ \\
\hline Asian & $\begin{array}{l}-0.040 \\
(0.033)\end{array}$ & $\begin{array}{c}0.960 \\
(0.032)\end{array}$ & $\begin{array}{c}-0.004 \\
(0.003)\end{array}$ & $\begin{array}{c}-0.022 \\
(0.018)\end{array}$ & $\begin{array}{l}-\mathbf{0 . 0 0 4} \\
(0.003)\end{array}$ & $\begin{array}{l}-0.036 \\
(0.055)\end{array}$ & $\begin{array}{c}0.965 \\
(0.053)\end{array}$ & $\begin{array}{l}-0.004 \\
(0.006)\end{array}$ & $\begin{array}{r}-0.019 \\
(0.03)\end{array}$ & $\begin{array}{l}-0.004 \\
(0.006)\end{array}$ \\
\hline Other & $\begin{array}{l}-0.506^{*} \\
(0.147)\end{array}$ & $\begin{array}{l}0.603^{*} \\
(0.089)\end{array}$ & $\begin{array}{c}-0.043^{*} \\
(0.01)\end{array}$ & $\begin{array}{c}-0.261^{*} \\
(0.074)\end{array}$ & $\begin{array}{c}-\mathbf{0 . 0 4 2} \\
(0.01)\end{array}$ & $\begin{array}{l}-0.536 \\
(0.344)\end{array}$ & $\begin{array}{c}0.585 \\
(0.201)\end{array}$ & $\begin{array}{c}-0.05^{* *} \\
(0.026)\end{array}$ & $\begin{array}{c}-0.30^{* *} \\
(0.174)\end{array}$ & $\begin{array}{c}-0.055^{* *} \\
(0.026)\end{array}$ \\
\hline educ99 & $\begin{array}{c}0.01 * \\
(0.003)\end{array}$ & $\begin{array}{l}1.01^{*} \\
(0.003)\end{array}$ & $\begin{array}{c}0.002^{*} \\
(0.0003)\end{array}$ & $\begin{array}{l}0.005^{*} \\
(0.001)\end{array}$ & $\begin{array}{c}0.001^{*} \\
(0.0003)\end{array}$ & $\begin{array}{c}0.035^{*} \\
(0.004)\end{array}$ & $\begin{array}{l}1.036^{*} \\
(0.005)\end{array}$ & $\begin{array}{c}0.005^{*} \\
(0.0006)\end{array}$ & $\begin{array}{l}0.019^{*} \\
(0.002)\end{array}$ & $\begin{array}{l}0.004^{*} \\
(0.001)\end{array}$ \\
\hline age & $\begin{array}{l}0.032^{*} \\
(0.003)\end{array}$ & $\begin{array}{l}1.032^{*} \\
(0.003)\end{array}$ & $\begin{array}{c}-0.003^{*} \\
(0.0003)\end{array}$ & $\begin{array}{l}0.014^{*} \\
(0.002)\end{array}$ & $\begin{array}{c}0.003^{*} \\
(0.0003)\end{array}$ & $\begin{array}{c}0.0202^{*} \\
(0.005)\end{array}$ & $\begin{array}{l}1.02 * \\
(0.005)\end{array}$ & $\begin{array}{c}-0.006^{*} \\
(0.001)\end{array}$ & $\begin{array}{l}0.005^{*} \\
(0.003)\end{array}$ & $\begin{array}{c}0.001^{*} \\
(0.0006)\end{array}$ \\
\hline sex & $\begin{array}{l}-0.48^{*} \\
(0.012)\end{array}$ & $\begin{array}{l}0.621^{*} \\
(0.008)\end{array}$ & $\begin{array}{c}-0.049^{*} \\
(0.001)\end{array}$ & $\begin{array}{l}-0.253^{*} \\
(0.007)\end{array}$ & $\begin{array}{c}-0.048^{*} \\
(0.001)\end{array}$ & $\begin{array}{c}-0.396^{*} \\
(0.02)\end{array}$ & $\begin{array}{l}0.673^{*} \\
(0.014)\end{array}$ & $\begin{array}{c}-0.048^{*} \\
(0.002)\end{array}$ & $\begin{array}{c}-0.215^{*} \\
(0.011)\end{array}$ & $\begin{array}{c}-0.047^{*} \\
(0.002)\end{array}$ \\
\hline Child & $\begin{array}{l}0.095^{*} \\
(0.006)\end{array}$ & $\begin{array}{l}1.099^{*} \\
(0.007)\end{array}$ & $\begin{array}{c}0.011^{*} \\
(0.0007)\end{array}$ & $\begin{array}{l}0.052^{*} \\
(0.003)\end{array}$ & $\begin{array}{l}0.001^{*} \\
(0.001)\end{array}$ & $\begin{array}{l}0.059^{*} \\
(0.01)\end{array}$ & $\begin{array}{l}1.06^{*} \\
(0.011)\end{array}$ & $\begin{array}{c}0.008^{*} \\
(0.002)\end{array}$ & $\begin{array}{c}0.035^{*} \\
(0.006)\end{array}$ & $\begin{array}{l}0.008^{*} \\
(0.001)\end{array}$ \\
\hline cons & $\begin{array}{l}-3.23^{*} \\
(0.076)\end{array}$ & & $\begin{array}{l}0.125^{*} \\
(0.007)\end{array}$ & $\begin{array}{l}-1.75^{*} \\
(0.04)\end{array}$ & & $\begin{array}{l}-3.24^{*} \\
(0.144)\end{array}$ & & $\begin{array}{l}0.141^{*} \\
(0.015)\end{array}$ & $\begin{array}{l}-1.73^{*} \\
(0.077)\end{array}$ & \\
\hline marst & yes & yes & yes & yes & yes & yes & yes & yes & yes & yes \\
\hline year & yes & yes & yes & yes & yes & yes & yes & yes & yes & yes \\
\hline region & no & no & no & no & no & no & no & no & no & no \\
\hline cohort & no & no & no & no & no & no & no & no & no & no \\
\hline metro & no & no & no & no & no & no & no & no & no & no \\
\hline
\end{tabular}

Other Controls: Marital Status, race, year,AGESQ. A/A/E American Indian/Aleut/Eskimo

$* 5 \%$ significance ${ }^{* *} 10 \%$ significance 


\subsection{Exposed African-Americans versus Non exposed African-Americans. Understanding the Institution-Information-self-employment channel}

In section 3, we argued that past institutions, information, and perceptions passed from one generation to the next play a significant role in framing the African-American view of self-employment and the likelihood of success if self-employment is undertaken. If we assume that the major obstacles to Black self-employment is capital and inter generational wealth transfers, both foreign Blacks and U.S born Blacks face similar obstacles. Also, in the case of racial discrimination, both U.S born Blacks and foreign Blacks face the same challenges. In addition, foreign Blacks have the institutional, administrative, and language issues with which they must contend. Hence, one would expect, a prioi, that foreign Blacks would have more difficulty obtaining work in the formal labor market than do U.S. born Blacks and would therefore more readily seek self-employment. The impacts of institutional constraints and barriers on naturalized and foreign Blacks relative to the impacts of long-term institutional shocks and generational information matrices will determine the relative self-employment probabilities between foreign born Blacks and U.S. born Blacks. Since institutional shocks and information difference would tend to reduce U.S. born Black self-employment probabilities whereas institutional, administrative, and language barriers would tend to increase foreign and naturalized Black self-employment we expect self-employment probabilities for U.S. born Blacks to be lower than those of naturalized and/or foreign Blacks. ${ }^{10}$

The decomposition of the sample into FB, FW, NAW and NAB, produce interesting results. However, these groups are not ideal for comparison to the U.S Blacks and Whites since they face differing institutional constraints that may not be adequately represented in the empirical model. Further, as Bogan and Darity (2008) argue, some groups have access to resources not observed in the data. Moreover, NAB and NAW who may not face the same formal institutional constraints as FB and FW, however, all four groups are impacted by informal constraints such as language barrier and accent, which could lead to informal discriminatory practices. Hence, to provide evidence of the impact of negative generational information stocks which are related to repeated institutional changes, past business failure, and unfair formal and informal legal practices, we must identify two

\footnotetext{
${ }^{10}$ Notice that if we compare FB to US born Whites it might seem that the argument of foreigners moving more into self-employment because of institutional barrier is not valid because self-employment rates for FB is lower than US born Whites. However, because of the potential of racial discrimination and capital resource availability both of which we cannot control for adequately, a better comparison group for FB is U.S. born Black and for FWDC is U.S. born Whites. Although such comparisons also have limitations,
} 
groups that faced similar discriminatory practices and institutional constraints. The only difference between these two groups should be their exposure to different historical information matrices.

\section{Why the Identification strategy can provide evidence for the role of information}

To identify the two groups of interest, we decompose U.S. citizens as in Belton and Oyelere(2008) by parents birth place. We decompose the sample of Black Americans into those with U.S. born parents (AAUBP), those with foreign born Mothers (AAFBM), those with foreign born Father (AAFBF), and African-American with both parents foreign born(AAFBP). We decompose the White sample in similar ways into White Americans with U.S. born parents (WAUBP), White Americans with foreign born Mothers (WAFBM), White Americans with foreign born Father (WAFBF) and White Americans with both parents foreign born (WAFBP).

From an institutional perspective, this decomposition helps to identify sub-groups who were likely exposed to institutional disincentive as it relates to self-employment. AAUBP, AAFBM, and AAFBF are more likely to have been exposed to historical institutions and information matrices that created self-employment disincentives for Blacks. ${ }^{11}$ We make this argument because most AAUBP are descendants of slaves, who through informal practices and word-of-mouth passed on experiences created by negative institutional shocks, thus building an information stock on which self-employment decisions are based. However, AAFBP are descendants from recent immigrants whose parents did not experience institutional shocks and business failures faced by the parents and grandparents of their counterparts. The information matrix of AAFBP is based on current conditions in the U.S. and the information stocks of their immigrant parents. ${ }^{12}$ Conversely, basing there forecasts on many historical examples, African-Americans with several generations in the U.S. have learned that most Black business are not likely to succeed. Even when most institutional constraints that lead to Black enterprize failures no longer exists, the information set which suggests failure for Black enterprizes persist across generations. Hence, AAUBP's decisions on self-employment although partly based on current conditions, are influenced by negative past experiences of the

\footnotetext{
${ }^{11}$ For AAFBM their exposure comes through their U.S. fathers while for AAFBF, their exposure comes through their U.S. born mothers. However, the extent of the influence of the U.S born parents or the foreign born parent is unclear. We do not encounter this problem when we consider African-Americans with both parents born in the U.S.

${ }^{12}$ The parents of AAFBP are immigrants and should have information stocks which are similar to those of their fellow immigrants. This stocks is based on conditions they experienced upon arrival in the U.S. They are not likely to base their success in self-employment on events they never experienced or the past happenings to African-American businesses but rather the experiences of other immigrants especially from their home country and continent who are usually their reference group.
} 
African-American community. In contrast, their counterparts, AAFBP, are more likely, given their parents successful migration to the U.S., to view America as the land of opportunities. In effect, their view of discrimination and self-employment is likely to be based on current U.S. conditions and the information channels of their parents described in Figure 1.

\section{Prediction and Empirical Evidence}

If discriminatory institutions and the information set derived there from, are not significant factors in the self-employment decision then, after accounting for all of the well documented factors that impacts the self-employment choice, we would expect similar self-employment probabilities for AAFBP, AAUBP, AAFBF, AAFBM, WAFBP, WAFBM, WAFBF, and WAUBP. Similarly, if racial discrimination was the only significant factor and institutions had no role, then after accounting for all well documented factors that impact the choice of self-employment, we should expect similar self-employment probabilities for AAFBP, AAUBP, AAFBF and AAFBM, but higher self employment probabilities for WAFBP, WAFBM, WAFBF, and WAUBP. ${ }^{13}$ Given the hypothesized impact of institutions on the self-employment decision, we expect AAUBP to have significantly lower probabilities of self-employment than any other group. However, it is unclear as to the how institutions impacted mixed families (AAFBF and AAFBM ) where only one parents has a high probability of exposure to information altering institutions. The literature on household bargaining behavior such as Bourguignon and Chiappori (1994) predicts the parent with the most bargaining power is likely to be dominant player in providing information to their offsprings. In many traditional homes across many cultures, men have more bargaining power in the family in terms of external choices such as employment choices, religious beliefs, and education. More specifically, a portion of the self-employment literature does emphasizes the role of fathers in self-employment decisions ${ }^{14}$. These papers provide evidence that having a father who was self-employed significantly increases the chances of a child pursuing a similar path. Given the literature on bargaining power, and the role of fathers, we argue AAFBF are likely to share a similar self-employment information matrix to that of AAFBP, while AAFBM are more likely to share a similar information matrix to that of AAUBP. Hence, we predict similar self-employment probabilities for AAFBF and AAFBP and similar probabilities for AAUBP and AAFBM.

\footnotetext{
${ }^{13}$ This prediction also implies similar self employment probabilities for WAFBP, WAFBM, WAFBF, and WAUBP.

${ }^{14}$ Hout and Ronsen(2000) Colombier and Masclet (2006) and Farlie (1999) are a few examples.
} 
Table 6: Identifying the Impact of Past Institutions on Self-Employment Gap

\begin{tabular}{|c|c|c|c|c|c|c|c|c|c|c|}
\hline \multirow[t]{2}{*}{ Variable: } & \multicolumn{5}{|c|}{ Saving Indicator 1} & \multicolumn{5}{|c|}{ Savings Indicator 2} \\
\hline & $\begin{array}{l}\operatorname{logit} \\
(1)\end{array}$ & $\begin{array}{c}\text { logistic } \\
(2)\end{array}$ & $\begin{array}{c}\text { Linear } \\
(3)\end{array}$ & $\begin{array}{c}\text { Probit } \\
(4)\end{array}$ & $\begin{array}{c}\text { dprobit } \\
(5)\end{array}$ & $\begin{array}{c}\operatorname{logit} \\
(6)\end{array}$ & $\begin{array}{c}\text { logistic } \\
(7)\end{array}$ & $\begin{array}{c}\text { Linear } \\
(8)\end{array}$ & $\begin{array}{c}\text { Probit } \\
(9)\end{array}$ & $\begin{array}{c}\text { dprobit } \\
\text { (10) }\end{array}$ \\
\hline & 1 & 2 & 3 & 4 & 5 & 6 & 7 & 8 & 9 & 10 \\
\hline logincint & $\begin{array}{c}0.095^{*} \\
(0.003)\end{array}$ & $\begin{array}{l}1.099^{*} \\
(0.003)\end{array}$ & $\begin{array}{c}0.01^{*} \\
(0.0003)\end{array}$ & $\begin{array}{c}0.05^{*} \\
(0.002)\end{array}$ & $\begin{array}{c}0.009^{*} \\
(0.0003)\end{array}$ & & & & & \\
\hline logdefinc & & & & & & $\begin{array}{c}0.054^{*} \\
(0.005)\end{array}$ & $\begin{array}{c}1.055^{*} \\
(0.005)\end{array}$ & $\begin{array}{c}0.006^{*} \\
(0.001)\end{array}$ & $\begin{array}{l}0.029^{*} \\
(0.003)\end{array}$ & $\begin{array}{l}0.006^{*} \\
(0.001)\end{array}$ \\
\hline AAFBM & $\begin{array}{c}-0.804^{*} \\
(0.411)\end{array}$ & $\begin{array}{c}0.448^{*} \\
(0.184)\end{array}$ & $\begin{array}{c}-0.044^{*} \\
(0.017)\end{array}$ & $\begin{array}{c}-0.386^{*} \\
(0.195)\end{array}$ & $\begin{array}{c}-\mathbf{0 . 0 5 7} \\
(0.021)\end{array}$ & $\begin{array}{l}-0.941 \\
(0.728)\end{array}$ & $\begin{array}{c}0.390 \\
(0.284)\end{array}$ & $\begin{array}{c}-0.059^{* *} \\
(0.031)\end{array}$ & $\begin{array}{l}-0.510 \\
(0.333)\end{array}$ & $\begin{array}{l}-0.083 \\
(0.037)\end{array}$ \\
\hline AAFBF & $\begin{array}{l}-0.052 \\
(0.345)\end{array}$ & $\begin{array}{l}0.949 \\
(0.33)\end{array}$ & $\begin{array}{c}-0.005 \\
(0.0288)\end{array}$ & $\begin{array}{c}-0.01 \\
(0.176)\end{array}$ & $\begin{array}{c}-\mathbf{0 . 0 0 2} \\
(0.033)\end{array}$ & $\begin{array}{c}0.146 \\
(0.646)\end{array}$ & $\begin{array}{c}1.16 \\
(0.748)\end{array}$ & $\begin{array}{c}0.015 \\
(0.067)\end{array}$ & $\begin{array}{l}0.109 \\
(0.33)\end{array}$ & $\begin{array}{c}0.025 \\
(0.082)\end{array}$ \\
\hline AAFBP & $\begin{array}{c}0.616 \\
(0.589)\end{array}$ & $\begin{array}{l}1.850 \\
(1.09)\end{array}$ & $\begin{array}{c}0.033 \\
(0.037)\end{array}$ & $\begin{array}{c}0.282 \\
(0.288)\end{array}$ & $\begin{array}{c}\mathbf{0 . 0 6 2} \\
(0.073)\end{array}$ & $\begin{array}{l}-0.671 \\
(1.19)\end{array}$ & $\begin{array}{c}0.511 \\
(0.608)\end{array}$ & $\begin{array}{l}-0.038 \\
(0.078)\end{array}$ & $\begin{array}{l}-0.258 \\
(0.571)\end{array}$ & $\begin{array}{l}-0.047 \\
(0.092)\end{array}$ \\
\hline AAUBP & $\begin{array}{l}-0.866^{*} \\
(0.0403)\end{array}$ & $\begin{array}{l}0.421^{*} \\
(0.017)\end{array}$ & $\begin{array}{l}-0.059^{*} \\
(0.002)\end{array}$ & $\begin{array}{c}-0.427^{*} \\
(0.019)\end{array}$ & $\begin{array}{c}-\mathbf{0 . 0 6 3} \\
(0.002)\end{array}$ & $\begin{array}{c}-0.871^{*} \\
(0.08)\end{array}$ & $\begin{array}{l}0.419^{*} \\
(0.034)\end{array}$ & $\begin{array}{c}-0.068^{*} \\
(0.005)\end{array}$ & $\begin{array}{l}-0.437^{*} \\
(0.039)\end{array}$ & $\begin{array}{l}-0.076^{*} \\
(0.005)\end{array}$ \\
\hline WAFBP & $\begin{array}{l}-0.082 \\
(0.061)\end{array}$ & $\begin{array}{c}0.922 \\
(0.056)\end{array}$ & $\begin{array}{l}-0.011 \\
(0.007)\end{array}$ & $\begin{array}{c}-0.04 \\
(0.033)\end{array}$ & $\begin{array}{l}-\mathbf{0 . 0 0 7} \\
(0.006)\end{array}$ & $\begin{array}{l}-0.112 \\
(0.094)\end{array}$ & $\begin{array}{c}0.894 \\
(0.084)\end{array}$ & $\begin{array}{c}-0.016 \\
(0.0132)\end{array}$ & $\begin{array}{l}-0.059 \\
(0.053)\end{array}$ & $\begin{array}{l}-0.013 \\
(0.011)\end{array}$ \\
\hline WAFBM & $\begin{array}{c}-0.024 \\
(0.039)\end{array}$ & $\begin{array}{c}0.976 \\
(0.038)\end{array}$ & $\begin{array}{l}-0.002 \\
(0.004)\end{array}$ & $\begin{array}{l}-0.015 \\
(0.021)\end{array}$ & $\begin{array}{r}-\mathbf{0 . 0 0 3} \\
(0.004)\end{array}$ & $\begin{array}{c}0.005 \\
(0.0602)\end{array}$ & $\begin{array}{c}1.00 \\
(0.061)\end{array}$ & $\begin{array}{c}0.001 \\
(0.008)\end{array}$ & $\begin{array}{c}0.001 \\
(0.033)\end{array}$ & $\begin{array}{l}0.0002 \\
(0.007)\end{array}$ \\
\hline WAFBF & $\begin{array}{c}0.029 \\
(0.036)\end{array}$ & $\begin{array}{c}1.03 \\
(0.036)\end{array}$ & $\begin{array}{l}0.005 \\
(0.004)\end{array}$ & $\begin{array}{c}0.017 \\
(0.019)\end{array}$ & $\begin{array}{c}\mathbf{0 . 0 0 3} \\
(0.004)\end{array}$ & $\begin{array}{c}0.092^{* *} \\
(0.053)\end{array}$ & $\begin{array}{c}1.096^{* *} \\
(0.056)\end{array}$ & $\begin{array}{c}0.014^{* *} \\
(0.008)\end{array}$ & $\begin{array}{c}0.056^{* *} \\
(0.03)\end{array}$ & $\begin{array}{r}0.013^{* *} \\
(0.007)\end{array}$ \\
\hline $\mathrm{FB}$ & $\begin{array}{c}-0.601^{*} \\
(0.148)\end{array}$ & $\begin{array}{l}0.548^{*} \\
(0.081)\end{array}$ & $\begin{array}{l}-0.042^{*} \\
(0.008)\end{array}$ & $\begin{array}{c}-0.303^{*} \\
(0.072)\end{array}$ & $\begin{array}{c}-\mathbf{0 . 0 4 7} \\
(0.009)\end{array}$ & $\begin{array}{c}-0.796^{*} \\
(0.36)\end{array}$ & $\begin{array}{c}0.451^{*} \\
(0.162)\end{array}$ & $\begin{array}{l}-0.056^{*} \\
(0.019)\end{array}$ & $\begin{array}{c}-0.435^{*} \\
(0.171)\end{array}$ & $\begin{array}{c}-0.074^{*} \\
(0.021)\end{array}$ \\
\hline FWLDC & $\begin{array}{c}-0.101^{*} \\
(0.047)\end{array}$ & $\begin{array}{l}0.904^{*} \\
(0.043)\end{array}$ & $\begin{array}{l}-0.009^{*} \\
(0.004)\end{array}$ & $\begin{array}{c}-0.051^{*} \\
(0.024)\end{array}$ & $\begin{array}{c}-\mathbf{0 . 0 0 9 *} \\
(0.004)\end{array}$ & $\begin{array}{c}0.048 \\
(0.118)\end{array}$ & $\begin{array}{c}1.049 \\
(0.124)\end{array}$ & $\begin{array}{c}0.006 \\
(0.013)\end{array}$ & $\begin{array}{c}0.028 \\
(0.063)\end{array}$ & $\begin{array}{c}0.006 \\
(0.014)\end{array}$ \\
\hline FWDC & $\begin{array}{l}0.305^{*} \\
(0.061)\end{array}$ & $\begin{array}{c}1.36^{*} \\
(0.083)\end{array}$ & $\begin{array}{l}0.036^{*} \\
(0.008)\end{array}$ & $\begin{array}{l}0.164^{*} \\
(0.034)\end{array}$ & $\begin{array}{c}\mathbf{0 . 0 3 4} * \\
(0.008)\end{array}$ & $\begin{array}{c}0.34^{*} \\
(0.104)\end{array}$ & $\begin{array}{l}1.40^{*} \\
(0.15)\end{array}$ & $\begin{array}{l}0.045^{*} \\
(0.015)\end{array}$ & $\begin{array}{l}0.185^{*} \\
(0.056)\end{array}$ & $\begin{array}{l}0.045^{*} \\
(0.015)\end{array}$ \\
\hline NAW & $\begin{array}{c}0.15^{*} \\
(0.033)\end{array}$ & $\begin{array}{c}1.16^{*} \\
(0.038)\end{array}$ & $\begin{array}{l}0.021^{*} \\
(0.004)\end{array}$ & $\begin{array}{l}0.085^{*} \\
(0.018)\end{array}$ & $\begin{array}{c}\mathbf{0 . 0 1 7} \\
(0.004)\end{array}$ & $\begin{array}{l}0.178^{*} \\
(0.058)\end{array}$ & $\begin{array}{c}1.19^{*} \\
(0.069)\end{array}$ & $\begin{array}{c}0.027^{*} \\
(0.009)\end{array}$ & $\begin{array}{c}0.106^{*} \\
(0.033)\end{array}$ & $\begin{array}{r}0.0246^{*} \\
(0.008)\end{array}$ \\
\hline NAB & $\begin{array}{c}-0.481^{*} \\
(0.133)\end{array}$ & $\begin{array}{l}0.618^{*} \\
(0.082)\end{array}$ & $\begin{array}{c}-0.043^{*} \\
(0.01)\end{array}$ & $\begin{array}{c}-0.252^{*} \\
(0.068)\end{array}$ & $\begin{array}{c}-\mathbf{0 . 0 4 0 3}^{*} \\
(0.01)\end{array}$ & $\begin{array}{l}-0.365 \\
(0.257)\end{array}$ & $\begin{array}{c}0.694 \\
(0.179)\end{array}$ & $\begin{array}{l}-0.036 \\
(0.023)\end{array}$ & $\begin{array}{l}-0.176 \\
(0.135)\end{array}$ & $\begin{array}{l}-0.035 \\
(0.024)\end{array}$ \\
\hline $\mathrm{A} / \mathrm{A} / \mathrm{E}$ & $\begin{array}{c}-0.195^{*} \\
(0.092)\end{array}$ & $\begin{array}{l}0.823^{*} \\
(0.076)\end{array}$ & $\begin{array}{c}-0.017^{*} \\
(0.008)\end{array}$ & $\begin{array}{c}-0.093^{* *} \\
(0.048)\end{array}$ & $\begin{array}{c}-\mathbf{0 . 0 1 7} \\
(0.008)\end{array}$ & $\begin{array}{l}-0.203 \\
(0.159)\end{array}$ & $\begin{array}{c}0.816 \\
(0.130)\end{array}$ & $\begin{array}{l}-0.021 \\
(0.015)\end{array}$ & $\begin{array}{c}-0.1 \\
(0.084)\end{array}$ & $\begin{array}{l}-0.021 \\
(0.016)\end{array}$ \\
\hline Asian & $\begin{array}{l}-0.042 \\
(0.033)\end{array}$ & $\begin{array}{c}0.958 \\
(0.032)\end{array}$ & $\begin{array}{l}-0.004 \\
(0.003)\end{array}$ & $\begin{array}{r}-0.0229 \\
(0.018)\end{array}$ & $\begin{array}{r}-\mathbf{0 . 0 0 4} \\
(0.003)\end{array}$ & $\begin{array}{l}-0.033 \\
(0.055)\end{array}$ & $\begin{array}{c}0.968 \\
(0.054)\end{array}$ & $\begin{array}{l}-0.004 \\
(0.006)\end{array}$ & $\begin{array}{l}-0.017 \\
(0.03)\end{array}$ & $\begin{array}{l}-0.004 \\
(0.006)\end{array}$ \\
\hline Other & $\begin{array}{c}-0.508^{*} \\
(0.147)\end{array}$ & $\begin{array}{l}0.601^{*} \\
(0.088)\end{array}$ & $\begin{array}{c}-0.043^{*} \\
(0.01)\end{array}$ & $\begin{array}{c}-0.262^{*} \\
(0.074)\end{array}$ & $\begin{array}{c}-\mathbf{0 . 0 4 2} \\
(0.01)\end{array}$ & $\begin{array}{l}-0.532 \\
(0.344)\end{array}$ & $\begin{array}{c}0.587 \\
(0.202)\end{array}$ & $\begin{array}{c}-0.05^{* *} \\
(0.026)\end{array}$ & $\begin{array}{c}-0.296^{* *} \\
(0.174)\end{array}$ & $\begin{array}{c}-0.054^{* *} \\
(0.026)\end{array}$ \\
\hline education & $\begin{array}{l}0.012^{*} \\
(0.003)\end{array}$ & $\begin{array}{l}1.01^{*} \\
(0.003)\end{array}$ & $\begin{array}{c}0.002^{*} \\
(0.0003)\end{array}$ & $\begin{array}{l}0.005^{*} \\
(0.001)\end{array}$ & $\begin{array}{c}0.001^{*} \\
(0.0003)\end{array}$ & $\begin{array}{c}0.0352^{*} \\
(0.004)\end{array}$ & $\begin{array}{l}1.036^{*} \\
(0.005)\end{array}$ & $\begin{array}{c}0.005^{*} \\
(0.0006)\end{array}$ & $\begin{array}{l}0.019^{*} \\
(0.002)\end{array}$ & $\begin{array}{l}0.004^{*} \\
(0.001)\end{array}$ \\
\hline
\end{tabular}

Other Controls: Marital Status, race, year, age, no of children, agesq. A/A/E American Indian/Aleut/Eskimo

* $5 \%$ significance ${ }^{* *} 10 \%$ significance 
We once again estimate a probability model of self-employment similar to equation 1 . Decomposing race into 16 categories; AAUBP, AAFBP, AAFBM, AAFBF, NAB, FB, WAUBP, WAFBP, WAFBM, WAFBF, NAW, FWLDC, FWDC, Asia, others and A/A/E/ ${ }^{15}$ The results of Table 6 provide support for our hypotheses. Using interest income as a wealth proxy, focusing on column (5) we find that AAUBP still maintain the lowest probability of self-employment relative to the base group, WAUBP, while AAFBP share similar self-employment probabilities to that of the base group. Moreover, our results reveal that AAFBP, WAUBP, WAFBP, WAFBM, WAFBF all share similar self-employment probabilities. FB, as noted in earlier regressions, have a lower potential for self-employment than do all Whites but higher than AAUBP. Results for all other racial categories are similar to earlier regressions. Interestingly, results reveal that AAFBF have a similar self-employment probability to that of the base group, WAUBP while AAFBM have a $5.7 \%$ lower probability of self-employment relative to the base group. The $5.7 \%$ lower probability for AAFBM is not statistically different from the $6.3 \%$ lower probability for AAUBP, providing further support for the literature which suggest that the role of the father is most important in the self-employment decisions. Table 6 provides significant support for our hypothesis in that after accounting for the important factors impacting the self-employment decision such as martial status, education, age, sex, number of children and wealth, we find that comparable AAUPB and AAFBP have different probabilities of self-employment although they face similar racial challenges in the labor market. Our explanation for this gap is the difference in the information matrix derived from differential institutional experiences faced by each group, leading ultimately to divergent self-employment probabilities. In contrast, comparable WAFBP and WAUBF share a similar though not identical information matrix but share similar self-employment probabilities. The results using the second wealth indicator are similar to the first though the gaps in the probabilities of self-employment for AAUBP, FB and AAFBM are larger. However, inferences from the result are the same and point to the impact of the unique information matrix faced by African Americans on their self-employment decision. 
Table 7: Robustness Checks: Adding on all the controls LDC vs DC and Self-Employment Gap

\begin{tabular}{|c|c|c|c|c|c|c|c|c|c|c|}
\hline \multirow[t]{2}{*}{ Variable: } & \multicolumn{5}{|c|}{ Saving Indicator 1} & \multicolumn{5}{|c|}{ Savings Indicator 2} \\
\hline & $\begin{array}{l}\operatorname{logit} \\
(1)\end{array}$ & $\begin{array}{c}\text { logistic } \\
(2)\end{array}$ & $\begin{array}{c}\text { Linear } \\
(3)\end{array}$ & $\begin{array}{c}\text { Probit } \\
(4)\end{array}$ & $\begin{array}{c}\text { dprobit } \\
(5)\end{array}$ & $\begin{array}{c}\operatorname{logit} \\
(6)\end{array}$ & $\begin{array}{c}\text { logistic } \\
(7)\end{array}$ & $\begin{array}{c}\text { Linear } \\
(8)\end{array}$ & $\begin{array}{c}\text { Probit } \\
(9)\end{array}$ & $\begin{array}{c}\text { dprobit } \\
(10)\end{array}$ \\
\hline & 1 & 2 & 3 & 4 & 5 & 6 & 7 & 8 & 9 & 10 \\
\hline logincint & $\begin{array}{c}0.091^{*} \\
(0.003)\end{array}$ & $\begin{array}{l}1.096^{*} \\
(0.004)\end{array}$ & $\begin{array}{c}0.01^{*} \\
(0.0003)\end{array}$ & $\begin{array}{c}0.049^{*} \\
(0.002)\end{array}$ & $\begin{array}{c}0.009^{*} \\
(0.0003)\end{array}$ & & & & & \\
\hline logincdiv & & & & & & $\begin{array}{l}0.053^{*} \\
(0.005)\end{array}$ & $\begin{array}{l}1.055^{*} \\
(0.005)\end{array}$ & $\begin{array}{l}0.006^{*} \\
(0.001)\end{array}$ & $\begin{array}{l}0.029^{*} \\
(0.003)\end{array}$ & $\begin{array}{l}0.006^{*} \\
(0.001)\end{array}$ \\
\hline AAUBP & $\begin{array}{c}-0.754^{*} \\
(0.041)\end{array}$ & $\begin{array}{l}0.470^{*} \\
(0.019)\end{array}$ & $\begin{array}{r}-0.049^{*} \\
(0.002)\end{array}$ & $\begin{array}{c}-0.369^{*} \\
(0.02)\end{array}$ & $\begin{array}{c}-\mathbf{0 . 0 5 4 9} \\
(0.002)\end{array}$ & $\begin{array}{c}-0.797^{*} \\
(0.081)\end{array}$ & $\begin{array}{c}0.451^{*} \\
(0.036)\end{array}$ & $\begin{array}{l}-0.06^{*} \\
(0.005)\end{array}$ & $\begin{array}{c}-0.398^{*} \\
(0.04)\end{array}$ & $\begin{array}{l}-0.07^{*} \\
(0.005)\end{array}$ \\
\hline $\mathrm{FB}$ & $\begin{array}{c}-0.345^{*} \\
(0.148)\end{array}$ & $\begin{array}{l}0.708^{*} \\
(0.105)\end{array}$ & $\begin{array}{c}-0.019^{*} \\
(0.008)\end{array}$ & $\begin{array}{c}-0.173^{*} \\
(0.072)\end{array}$ & $\begin{array}{c}-\mathbf{0 . 0 2 8} \\
(0.0105)\end{array}$ & $\begin{array}{l}-0.632 \\
(0.367)\end{array}$ & $\begin{array}{c}0.532 \\
(0.193)\end{array}$ & $\begin{array}{c}-0.041^{*} \\
(0.019)\end{array}$ & $\begin{array}{c}-0.344^{*} \\
(0.172)\end{array}$ & $\begin{array}{l}-0.061^{*} \\
(0.024)\end{array}$ \\
\hline AAFBP & $\begin{array}{c}0.604 \\
(0.593)\end{array}$ & $\begin{array}{c}1.83 \\
(1.085)\end{array}$ & $\begin{array}{c}0.032 \\
(0.037)\end{array}$ & $\begin{array}{c}0.276 \\
(0.293)\end{array}$ & $\begin{array}{c}\mathbf{0 . 0 6} \\
(0.073)\end{array}$ & $\begin{array}{c}-0.726 \\
(1.202)\end{array}$ & $\begin{array}{c}0.484 \\
(0.582)\end{array}$ & $\begin{array}{l}-0.043 \\
(0.078)\end{array}$ & $\begin{array}{l}-0.303 \\
(0.580)\end{array}$ & $\begin{array}{l}-0.055 \\
(0.086)\end{array}$ \\
\hline $\mathrm{A} / \mathrm{A} / \mathrm{E}$ & $\begin{array}{c}-0.264^{*} \\
(0.093)\end{array}$ & $\begin{array}{l}0.768^{*} \\
(0.071)\end{array}$ & $\begin{array}{c}-0.025^{*} \\
(0.008)\end{array}$ & $\begin{array}{l}-0.129^{*} \\
(0.0485)\end{array}$ & $\begin{array}{c}-\mathbf{0 . 0 2 3} * \\
(0.008)\end{array}$ & $\begin{array}{c}-0.312^{*} \\
(0.161)\end{array}$ & $\begin{array}{c}0.732^{* *} \\
(0.118)\end{array}$ & $\begin{array}{c}-0.0358^{*} \\
(0.016)\end{array}$ & $\begin{array}{c}-0.157^{* *} \\
(0.087)\end{array}$ & $\begin{array}{c}-0.031^{* *} \\
(0.016)\end{array}$ \\
\hline Asian & $\begin{array}{l}-0.016 \\
(0.035)\end{array}$ & $\begin{array}{c}0.984 \\
(0.034)\end{array}$ & $\begin{array}{l}-0.003 \\
(0.003)\end{array}$ & $\begin{array}{l}-0.011 \\
(0.018)\end{array}$ & $\begin{array}{l}-0.002 \\
(0.003)\end{array}$ & $\begin{array}{l}-0.043 \\
(0.057)\end{array}$ & $\begin{array}{c}0.958 \\
(0.055)\end{array}$ & $\begin{array}{l}-0.006 \\
(0.007)\end{array}$ & $\begin{array}{l}-0.024 \\
(0.031)\end{array}$ & $\begin{array}{l}-0.005 \\
(0.007)\end{array}$ \\
\hline Other & $\begin{array}{c}-0.454^{*} \\
(0.148)\end{array}$ & $\begin{array}{l}0.635^{*} \\
(0.094)\end{array}$ & $\begin{array}{c}-0.039^{*} \\
(0.010)\end{array}$ & $\begin{array}{c}-0.229^{*} \\
(0.075)\end{array}$ & $\begin{array}{c}-\mathbf{0 . 0 3 6} \\
(0.01)\end{array}$ & $\begin{array}{l}-0.517 \\
(0.331)\end{array}$ & $\begin{array}{c}0.596 \\
(0.197)\end{array}$ & $\begin{array}{c}-0.048^{* *} \\
(0.026)\end{array}$ & $\begin{array}{l}-0.290 \\
(0.174)\end{array}$ & $\begin{array}{l}-0.053 \\
(0.026)\end{array}$ \\
\hline NAW & $\begin{array}{c}0.236^{*} \\
(0.033)\end{array}$ & $\begin{array}{l}1.27^{*} \\
(0.042)\end{array}$ & $\begin{array}{l}0.029^{*} \\
(0.005)\end{array}$ & $\begin{array}{l}0.129^{*} \\
(0.018)\end{array}$ & $\begin{array}{l}\mathbf{0 . 0 2 5} * \\
(0.004)\end{array}$ & $\begin{array}{l}0.219^{*} \\
(0.058)\end{array}$ & $\begin{array}{l}1.24^{*} \\
(0.072)\end{array}$ & $\begin{array}{c}0.03^{*} \\
(0.009)\end{array}$ & $\begin{array}{c}0.127^{*} \\
(0.033)\end{array}$ & $\begin{array}{l}0.029^{*} \\
(0.008)\end{array}$ \\
\hline NAB & $\begin{array}{c}-0.307^{*} \\
(0.133)\end{array}$ & $\begin{array}{l}0.735^{*} \\
(0.098)\end{array}$ & $\begin{array}{c}-0.027^{*} \\
(0.01)\end{array}$ & $\begin{array}{c}-0.162^{*} \\
(0.068)\end{array}$ & $\begin{array}{c}-\mathbf{0 . 0 2 7}{ }^{*} \\
(0.010)\end{array}$ & $\begin{array}{c}-0.284 \\
(0.259)\end{array}$ & $\begin{array}{c}0.753 \\
(0.195)\end{array}$ & $\begin{array}{l}-0.028 \\
(0.023)\end{array}$ & $\begin{array}{l}-0.126 \\
(0.139)\end{array}$ & $\begin{array}{l}-0.025 \\
(0.026)\end{array}$ \\
\hline FWLDC & $\begin{array}{c}0.023 \\
(0.048)\end{array}$ & $\begin{array}{l}1.024 \\
(0.049)\end{array}$ & $\begin{array}{c}0.001 \\
(0.004)\end{array}$ & $\begin{array}{c}0.012 \\
(0.025)\end{array}$ & $\begin{array}{c}\mathbf{0 . 0 0 2} \\
(0.005)\end{array}$ & $\begin{array}{c}0.143 \\
(0.119)\end{array}$ & $\begin{array}{c}1.154 \\
(0.137)\end{array}$ & $\begin{array}{c}0.015 \\
(0.013)\end{array}$ & $\begin{array}{c}0.077 \\
(0.064)\end{array}$ & $\begin{array}{c}0.017 \\
(0.015)\end{array}$ \\
\hline FWDC & $\begin{array}{l}0.355^{*} \\
(0.061)\end{array}$ & $\begin{array}{l}1.43^{*} \\
(0.087)\end{array}$ & $\begin{array}{l}0.041^{*} \\
(0.008)\end{array}$ & $\begin{array}{l}0.191^{*} \\
(0.034)\end{array}$ & $\begin{array}{l}\mathbf{0 . 0 3 9 *} \\
(0.008)\end{array}$ & $\begin{array}{l}0.342^{*} \\
(0.104)\end{array}$ & $\begin{array}{l}1.408^{*} \\
(0.146)\end{array}$ & $\begin{array}{c}0.0448^{*} \\
(0.015)\end{array}$ & $\begin{array}{l}0.186^{*} \\
(0.059)\end{array}$ & $\begin{array}{c}0.0444^{*} \\
(0.015)\end{array}$ \\
\hline WAFBP & $\begin{array}{c}-0.068 \\
(0.0613)\end{array}$ & $\begin{array}{c}0.934 \\
(0.057)\end{array}$ & $\begin{array}{l}-0.009 \\
(0.007)\end{array}$ & $\begin{array}{l}-0.032 \\
(0.033)\end{array}$ & $\begin{array}{c}-0.006 \\
(0.006)\end{array}$ & $\begin{array}{l}-0.103 \\
(0.095)\end{array}$ & $\begin{array}{c}0.902 \\
(0.086)\end{array}$ & $\begin{array}{l}-0.015 \\
(0.013)\end{array}$ & $\begin{array}{l}-0.056 \\
(0.053)\end{array}$ & $\begin{array}{c}-0.012 \\
(0.0108)\end{array}$ \\
\hline WAFBM & $\begin{array}{l}-0.013 \\
(0.039)\end{array}$ & $\begin{array}{c}0.987 \\
(0.039)\end{array}$ & $\begin{array}{c}-0.001 \\
(0.004)\end{array}$ & $\begin{array}{l}-0.011 \\
(0.021)\end{array}$ & $\begin{array}{r}-0.002 \\
(0.004)\end{array}$ & $\begin{array}{c}0.008 \\
(0.061)\end{array}$ & $\begin{array}{c}1.01 \\
(0.061)\end{array}$ & $\begin{array}{c}0.001 \\
(0.008)\end{array}$ & $\begin{array}{c}0.001 \\
(0.033)\end{array}$ & $\begin{array}{l}0.0002 \\
(0.007)\end{array}$ \\
\hline WAFBF & $\begin{array}{l}0.072^{*} \\
(0.035)\end{array}$ & $\begin{array}{l}1.07^{*} \\
(0.038)\end{array}$ & $\begin{array}{l}0.009^{*} \\
(0.004)\end{array}$ & $\begin{array}{l}0.038^{*} \\
(0.019)\end{array}$ & $\begin{array}{l}\mathbf{0 . 0 0 7 *} \\
(0.004)\end{array}$ & $\begin{array}{l}0.117^{*} \\
(0.053)\end{array}$ & $\begin{array}{l}1.12^{*} \\
(0.06)\end{array}$ & $\begin{array}{c}0.017^{*} \\
(0.008)\end{array}$ & $\begin{array}{c}0.069^{*} \\
(0.03)\end{array}$ & $\begin{array}{l}0.015^{*} \\
(0.007)\end{array}$ \\
\hline AAFBM & $\begin{array}{l}-0.691 \\
(0.416)\end{array}$ & $\begin{array}{c}0.501 \\
(0.209)\end{array}$ & $\begin{array}{c}-0.035^{*} \\
(0.017)\end{array}$ & $\begin{array}{l}-0.326 \\
(0.201)\end{array}$ & $\begin{array}{c}-\mathbf{0 . 0 4 8} \\
(0.023)\end{array}$ & $\begin{array}{l}-0.871 \\
(0.738)\end{array}$ & $\begin{array}{c}0.418 \\
(0.309)\end{array}$ & $\begin{array}{c}-0.055^{*} \\
(0.033)\end{array}$ & $\begin{array}{l}-0.458 \\
(0.339)\end{array}$ & $\begin{array}{c}-0.075^{*} \\
(0.04)\end{array}$ \\
\hline AAFBF & $\begin{array}{c}0.083 \\
(0.349)\end{array}$ & $\begin{array}{c}1.09 \\
(0.379)\end{array}$ & $\begin{array}{c}0.006 \\
(0.029)\end{array}$ & $\begin{array}{c}0.052 \\
(0.178)\end{array}$ & $\begin{array}{c}\mathbf{0 . 0 1} \\
(0.035)\end{array}$ & $\begin{array}{c}0.254 \\
(0.657)\end{array}$ & $\begin{array}{c}1.29 \\
(0.846)\end{array}$ & $\begin{array}{c}0.027 \\
(0.067)\end{array}$ & $\begin{array}{l}0.168 \\
(0.34)\end{array}$ & $\begin{array}{c}0.04 \\
(0.087)\end{array}$ \\
\hline educ99 & $\begin{array}{l}0.014^{*} \\
(0.003)\end{array}$ & $\begin{array}{l}1.014^{*} \\
(0.003)\end{array}$ & $\begin{array}{c}0.002^{*} \\
(0.0003)\end{array}$ & $\begin{array}{l}0.007^{*} \\
(0.001)\end{array}$ & $\begin{array}{c}0.001^{*} \\
(0.0003)\end{array}$ & $\begin{array}{c}0.039 * \\
(0.005) 7\end{array}$ & $\begin{array}{l}1.04^{*} \\
(0.005)\end{array}$ & $\begin{array}{l}0.005^{*} \\
(0.001)\end{array}$ & $\begin{array}{l}0.021^{*} \\
(0.003)\end{array}$ & $\begin{array}{l}0.005^{*} \\
(0.001)\end{array}$ \\
\hline cons & $\begin{array}{c}-2.63^{*} \\
(0.237)\end{array}$ & & $\begin{array}{c}0.114^{*} \\
(0.031)\end{array}$ & $\begin{array}{l}-1.51^{*} \\
(0.128)\end{array}$ & & $\begin{array}{l}-2.92^{*} \\
(0.411)\end{array}$ & & $\begin{array}{c}0.083 \\
(0.055)\end{array}$ & $\begin{array}{l}-1.66^{*} \\
(0.224)\end{array}$ & \\
\hline
\end{tabular}

Other Controls: Marital Status,sex, age, year,AGESQ, cohort, region, metro area, male with child, male married, head, family size, own home, child. A/A/E American Indian/Aleut/Eskimo

$* 5 \%$ significance $* * 10 \%$ significance 


\section{Robustness Checks}

In attempting to examine the robustness of our results, we estimate all the probability models controlling for additional factors that could be relevant in the self-employment decision. These factors include cohort of birth, region, whether an individual lives in a metro area, if observation is a male with child, if observation is male and married, family size, if the individual owns a home and the number of children. The results of this analysis are in Table 7, as with all other tables, we focus on estimates in columns (5) and (10). The results show that there are no differences in the probability of self-employment for WAFBP, WAUBP, WAFBM, AAFBF and AAFBP. However, AAUBP have a $5.5 \%$ less probability of self-employment, which is still the lowest of all self-employment probabilities across all groups. FB and NAB are the only other groups with lower probabilities of self-employment than that of the base group at $2.7 \%$ and $2.8 \%$, respectively. The addition of more controls variables, though useful, only lead to a slight reduction in most probabilities. The lower self-employment probabilities for FB and NAB may be capturing discrimination based on language and/or accent. However, one could argue that for FB, given their uncertain immigration status, self-employment may prove to be a significantly risky venture. The same rationale could apply to NAB who, in all likelihood, lived in the U.S. as FB before becoming citizens. However, NAB are no longer faced with legal citizenship constraints, which increases their chances of success in the formal labor market and could reduce their desire for self-employment. Finally, our results show lower self-employment probabilities for FB relative to FWLDC, leading us to conclude that discrimination could play a role in lower self-employment probabilities for Blacks.

It is important to mention that the interesting results in our analysis focused on foreigners could be biased. This is because our proxy for wealth may not be adequate for foreign born survey participants. Earlier we mentioned the possible role of external resources available to foreigners leading to higher self-employment rates highlighted by Bogan and Darity (2008). Belton and Oyelere (2008) discuss the difficulty in measuring wealth for foreigners and naturalized citizens given our inability to fully observe their savings in U.S. data sources. However, this issue is not cause for concern given that our identification strategy does not depend on estimates of those who are foreign born. The key result in this paper is that comparing AAUBP self-employment probabilities to those of AAFBP, WAUBP, and WAFBP provides evidence that there is more than discrimination

\footnotetext{
${ }^{15}$ for ease of presentation of results we only show the racial category variables, and highlight other control variable used under the table
} 
and/or resource availability to the lower self-employment probabilities for AAUBP. Both AAFBP and AAUBP are Black and targets of discrimination, and given that we proxy for wealth, there is no obvious reason as to why these two groups of American born Blacks should have such different self-employment probabilities but for the different historical information matrices to which they were exposed. Over time, the differences in information exposure has led to marked differences in current self-employment probabilities as AAUBP have the lowest probability of self-employment of any group.

\section{Inferences, Recommendations and Conclusions}

In this paper, we try to explain empirically the gap between Black and White Americans selfemployment after controlling for the typical factors that affect this rate. We first summarize the literature carefully discussing different explanations provided by recent research for this persistent gap. However, most research attempt to control for demographic, financial, and other reasons for the lower self-employment of African-Americans but still unexplained difference remain post estimation. In this paper we focus solely on recent data, hence, avoiding complications that make empirical research problematic prior to the 80's recession and the break down of segregation. We show that all important factors cited previously in the self-employment literature remain important in the data set used in this research. We then go a step further to describe what we believe to be the missing link in understanding African-American self-employment decisions.

We argue that the institutional history of African-American as it relates to self-employment as well as the information matrix derived from institutional experiences, interact in building an information stock which provides the foundation for African-American self-employment decisions. When societal groups experience many negative shocks from institutional failures that seem to lead to more difficult entry into self-employment and/or a higher probability of failure upon entry, then over time this information becomes embedded in the information stock that is is transmitted from one generation to the next. Even when the actual institutions that lead to self-employment failures and low success probabilities have disappeared, the stock of information remains and tends to impact perception of success and self-employment decisions over the long-run.

African-Americans have experienced several shocks that has impeded Black entrepreneurship and led to the failure of Black business. Hence, they share a unique information matrix unlike any other U.S. ethnic/racial group. Research has generally referred to the persistent gap in self-employment 
even after employing appropriate controls as the discrimination proxy for Blacks. Similar to other research we find suggestive evidence of discrimination. However, we show that there is a group of African-Americans who even in the face of discrimination, tend to select self-employment at the same rate as U.S. born White Americans. Though the birth place of parents of AAFBP and AAUBP differ, these groups are similar in every respect save the information sets to which they were exposed. Hence, we conclude that historical information channels provide the only significant factor that leads to differences in the self-employment behavior across the two groups. ${ }^{16}$ The AAFBP self-employment information matrix is based on the recent experiences of immigrants in the U.S. Conversely, the AAUBP self-employment information matrix is framed by all of the formal and informal institutional failures experienced by the African-American community over time. While both groups experience identical treatment in the labor market, the difference in information matrices created by divergent institutional experiences, leads to differences in the self-employment decision across the two groups.

The results found in this paper provides new information on African-American self-employment and it is our hope that these results will create a dialogue among economists. If African-Americans are overtly careful in their decision to enter self-employment because of past information and business failures that are no longer relevant, then given the successes of their "cousins" AAFBP, there is need for corrective policy action. Policy-makers must find a way to celebrate African-American business success providing positive images of self-employment success. In effect, we must find ways to incentivize African-Americans to try self-employment again.

\footnotetext{
${ }^{16}$ There may be slight differences in culture among these two groups linked with the cultural influences of the immigrant parent on AAFBP. However, there is no reseon to expect such differences to affect self employment. Recall that WAFBP and WAUBP though also with slight differences in culture, have similar self-employment probabilities.
} 


\section{References}

[1] Acemoglu, D., S. Johnson and J.A. Robinson (2001) The Colonial Origins of Comparative Development: An Empirical Investigation. American Economic Review 91(5): 1369-1401.

[2] Acemoglu, D., S. Johnson and J.A. Robinson (2002) Reversal of Fortune: Geography and Institutions in the Making of the Modern World Income Distribution, Quarterly Journal of Economics 117(4): 1231-1294.

[3] Belton, Willie \& Uwaifo Oyelere, Ruth, 2008. "The Racial Saving Gap Enigma: Unraveling the Role of Institutions," IZA Discussion Papers 3545, Institute for the Study of Labor (IZA).

[4] Bates, Timothy, "Self-Employed Minorities: Traits and Trends," Social Sciences Quarterly68 (Sept.1987), 539-550.

[5] Bates, Timothy. 1997. Race, Self-Employment \& Upward Mobility: An Illusive American Dream, Washington, D.C.: Woodrow Wilson Center Press and Baltimore: John Hopkins University Press.

[6] Bease, P.J. "An Econometric Analysis of Black Entrepreneauship," The Journal of Black Political Economy, pp. 111-134, 1984

[7] Blanchflower, David G. \& Phillip B. Levine \& David J. Zimmerman, 2003. "Discrimination in the Small-Business Credit Market," The Review of Economics and Statistics.

[8] Blau, Francine D \& Graham, John W, 1990. "Black-White Differences in Wealth and Asset Composition," The Quarterly Journal of Economics, MIT Press, vol. 105(2), pages 321-39, May

[9] Borjas, George J \& Bronars, Stephen G, 1989. "Consumer Discrimination and Selfemployment," Journal of Political Economy, University of Chicago Press, vol. 97(3), pages 581-605, June.

[10] Boston, Thomas and Catherine Ross. 1997. "Location Preferences of Successful AfricanAmerican-Owned Businesses in Atlanta.? In The Inner City, ed. Thomas Boston and Catherine Ross. New Brunswick, NJ: Transaction Publishers. 
[11] Bourguignon, F., Chiappori, P.-A. (1994). The Collective Approach to Household Behavior. In R. Blundell \& I. Preston \& I. Walker (Eds.), The Measurement of Household Welfare. Cambridge, U.K.: Cambridge University Press.

[12] Bogan, Vicki and William Darity. 2008. "Culture and Entrepreneurship? African-American and Immigrant Self-Employment in the United States," The Journal of Socio-Economics forthcoming 2008

[13] Boyd, R. L., 1990b. "Black Business Transformation, Black Well-Being, and Public Policy" Population Reserach and Policy Review, 9, pp.117-132

[14] Brimmer,A. F. "The Negro in the National Economy." The American Negro Reference Book, Prentice Hall Inc., Englewood Cliffs, NJ, pp 252-336, 1966

[15] Brimmer,A. F. "Income, Wealth, and Investment Behavior in the Black Community," American Economic Review 78(2), pp. 151-155, 1988

[16] Colombier, N. and Masclet, D. (2006) "Self-Employment and The Intergenerational Transmission of Human Capital" CIRANO Working Papers from CIRANO

[17] Darity, William Jr. "Stratification Economics : The Role of Intergroup Inequality," Journal of Economics and Finance 24(2):144-'153. Summer 2005

[18] Darity, W. and Frank, D., "The Economics of Reparations." American Economic Review 93(2), pp. 326-329

[19] Evans, David S. and Linda S. Leighton. 1989. "Why Do Smaller Firms Pay Less?" Journal of Human Resources 24(2):299-318.

[20] David G. Blanchflower and Andrew J. Oswald. 1998. "What Makes an Entrepreneur?" Journal of Labor Economics, 1998, 16, 26-60.

[21] Fairlie, Robert W. 1999. "The Absence of the African-American Owned Business: An Analysis of the Dynamics of Self-Employment." Journal of Labor Economics, 17(1): 80- 108.

[22] Fairlie, Robert W., and Bruce D. Meyer. 1996. "Ethnic and Racial Self-Employment Differences and Possible Explanations." Journal of Human Resources 31(4):757-793. 
[23] Fairlie, R. W., \& Meyer, B. D. 2000. Trends in Self-Employment Among White and Black Men During the Twentieth Century. The Journal of Human Resources, 35 (4), p. 643-669.

[24] Fairlie, Robert W. and Alicia M. Robb 2007 "Why Are Black-Owned Businesses Less Successful than White-Owned Businesses? The Role of Families, Inheritances, and Business Human Capital”. Journal of Labor Economics, 2007, vol. 25, issue 2, pages 289-324.

[25] Feagan, J.R. and N. Imani., 1994 "Racial Barriers to African-American Entrepreneauship: An Exploratory Study," Social Problem 41 (4), pp. 562-584.

[26] Frazier, E. 1965. Black Bourgeoisie. Glencoe, Ill

[27] Higgs, R., "Competition and Coersion: Blacks in the American Economy 1865-1914", Cambridge University Press, Cambridge, 1977

[28] Hout, M. and Rosen, H., 2000. "Self-Employment, Family Background and Race", Journal of Human Resources 35,(4), pp.670-692.

[29] Lentz, B. and Laband, D., 1990. "Entrepreneurial Success and Occupational Inheritance Among Proprietors," Canadian Journal of Economics, 23,(3), pp.563-579

[30] Light, I.,1980 Ethnic Entrepreneauship in America, University of California Press, Berkeley, California.

[31] Light, I., and Gold, S.J. 2000. Ethnic Economies, Academic Press. San Diego, California.

[32] Lofstrom, M.J. and Bates, T. 2007. "African Americans' Pursuit of Self-Employment" (with Timothy Bates), IZA DP No.

[33] McPherson, J.M., The Struggle for Equality: Abolitionists and Negro in the Civil War and Reconstrtuction., Princeton University Press, 1964

[34] North, Douglass C. and Robert Paul Thomas,. 1973. The Rise of the Western World: A New Economic History. New York: Cambridge University

[35] North, Douglass C. 2005. Understanding the Process of Economic ChangePrinceton, N.J.: Princeton University Press, 2005. xi +187 pp 
[36] North, Douglass C. 1990. Institutions, Institutional Change, and Economic Performance. New York: Cambridge University Press Press, 1973. viii +171 pp.

[37] Smith, J. and Welch, F.,1989. "Black Economic Progress After Myrdal," Journal of Economic Literature, 27(2), pp. 519-564,

[38] Sowell,T., 1991. Cultural Diversity: A World View, American Enterprise Institute 2(3), pp. 44-55.

[39] Sowell,T., 1994. Race and Culture: A World View. Harper-Collins, Basic Books, New York ,. 